\title{
Top incomes under finance-driven capitalism, 1990-2010: power resources and regulatory orders
}

\section{Eoin Flaherty*}

School of Sociology, Social Policy, and Social Work, Queen's University Belfast, Belfast, UK

*Correspondence: e.flaherty@qub.ac.uk

\begin{abstract}
This article examines the impact of financialization on the income shares of the top $1 \%$ from 1990 to 2010, through a panel analysis of 14 OECD countries. Drawing together literatures stressing the dependence of income inequality on the structural bargaining power of capital relative to labour, and of the dependence of accumulation on underlying institutionalized modes of state regulation, it shows that financialization has significantly enhanced top income shares net of underlying controls. Whilst the income shares of the top $1 \%$ appear responsive to variables typical of wider studies of personal income inequality, we emphasize distinctive mechanisms of top income growth linked to the rising dominance of financial instruments and actors, facilitated by a historically specific regulatory order. These conditions were key to the emergence of a state of 'asymmetric bargaining' which disproportionately enhanced the fortunes of the wealthy. Results thus emphasize the importance of class-biased power resources and underlying regulatory structures, as determinants both of income concentration and of the distribution of economic rewards beyond growth capacity alone.
\end{abstract}

Key words: inequality, financialization, bargaining, social structures, regulation

JEL classification: 015 Income Distribution, N2 Financial Markets and Institutions, P48 Political Economy

\section{Introduction}

Financialization has taken its place as a macro-stressor of income equality on a par with globalization, technological change and economic development. Kuznet's predictions of a secular return to equality following a disruptive phase of dualist economic growth have not come to pass (Alderson and Nielsen, 2002; Piketty, 2014), whilst globalization has merely hastened a loosening of domestic constraints on firm activity, exposing labour to international wage 
competition and the threat of firm relocation (Choi, 2001; Harrison, 2005; O' Farrell, 2010). Amid profound shifts in the global economic order since the 1980s, it is clear that a limited few have benefitted substantially, whilst many have seen their fortunes worsen-a situation brought into sharp relief by the socialization of private debt in the post-crisis years, and the damaging impact of austerity on low-income groups. Whilst some have stressed the dependence of inequality on capital-augmenting technological growth and labour substitution (Zuleta, 2012), others have pointed to institutional factors such as the strength of labour movements, leftist political power and state welfare intensities (Beckfield, 2006, 2009; Daudey and Garcia-Lenalosa, 2007). Backed by a strong and growing empirical knowledge base, the rise of finance has also been identified as a stressor of both personal income inequality, and of the division of national income between capital and labour (Kus, 2012; Volscho and Kelly, 2012; Lin and Tomaskovic-Devey, 2013; Stockhammer, 2013).

The landscape of inequality research has changed drastically on foot of the public exposure generated by Piketty's Capital in the Twenty-First Century (2014), wherein he outlines a model of income inequality which positions wealth accumulation as an inherent, rather than aberrant feature of capitalist history. Piketty links this accumulation to a fundamental divergence, where slow growth relative to higher capital returns reduces the volume of investment needed to increase personal wealth stocks. Whilst this ratio has remained skewed towards capital returns throughout much of human history, it also appears likely to return to such a state if capital taxation remains lax, and post-crisis growth remains slow. In some instances the recurrent rise in top incomes has been sharp. In the USA, the share of income accruing to the top $1 \%$ of earners began to climb in the 1980s following a post-war slump, today bringing it to levels not seen since the close of the First World War (Volscho and Kelly, 2012, p. 679). The implications of Piketty's framework for analyses of top incomes are profound. As the ratio of capital gains to growth, and ratio of capital to labour income both appear responsive to specific policy epochs, the social embeddedness and historical contingency of inequality is strongly asserted. Furthermore, as Piketty links the imbalance of capital-labour income and recent executive pay growth to the loosened bargaining constraints of top earners, it is useful to question what precisely has underpinned this inequality at the meso-level. This article argues that useful answers may be sought by focusing more clearly on asymmetries in power resources and the bargaining power of capital relative to labour, allied to a unique regulatory order which has underpinned top income growth since the 1980s. In doing so, it suggests that the historical specificity of these factors, and the mechanisms underpinning wealth accumulation since the 1990s, are usefully captured by the concept of financialization.

Financialization has been conceptualized in a variety of ways, such as the diversification of firms into financial activities away from core 'real economy' pursuits (Krippner, 2011), the growing use of securitization and tradable financial instruments as distributors of risk (Movitz and Allvin, 2014), a realignment of corporate strategies in favour of profiteering and cost saving (Thompson, 2003, 2013) and the use of credit to shore up consumption under real wage stagnation (Guttman, 2008; Stockhammer, 2012; Kus, 2013a; ILO, 2013; Tomaskovic-Devey and Lin, 2013; van der Zwan, 2014). In terms of class structure, the era of financialization has been characterized by the rise of what Foster and Holleman (2010) term a 'financial power elite', deriving their wealth from financial profits, real estate and executive compensation. Allied to such works on the general dynamics of finance-driven capitalism, a growing body of research has brought renewed attention to the structural powerlessness of labour relative to capital, and the institutionalization of liberal regulatory order since the 
1980s, factors strongly linked to greater accumulation at the top of the income distribution (Diwan, 2001; Guscina, 2006; Kristal, 2010). The growing powerlessness of labour since the birth of the era of financialization in the 1980s has been closely linked to the weakening of the labour movement under the combined pressures of service sector growth, labour market deregulation and the loosening of capital restraints as an engine of post-Fordist economic growth (Jessop, 2001, 2013; Blanchard and Giavazzi, 2003, Jayadev, 2007; Tabb, 2010). It thus appears that the fortunes of the 'winners' of finance-driven capitalism have clear social, political and policy underpinnings.

Evidence for financialization's specific impact on inequality continues to grow. Whilst financialization is shown to exert a strong depressive effect on wage shares (Stockhammer, 2013), Atkinson et al. (2010) are emphatic on the role of politics in determining top income movement. This model of politically, rather than market determined income distribution accords with rent theory accounts of the financial sector's increasing share of national income. Consequently, researchers in this vein note how market equilibria are politically structured, and that income advantage above market rates is often secured through political manipulation of regulatory structures (Tomaskovic-Devey and Lin, 2011, p. 541). Beyond macro-level accounts of top income growth linked to growth and capital return rates, these accounts lend strong credence to a power resources explanation of top income capture.

The rise of top income shares is of immediate practical concern. Whilst Stockhammer has demonstrated the slowdown effect of financialization on accumulation and investment (2004), Piketty's illustration of the long-run dynamics of capital relative to national income suggests that without political intervention to effect greater redistribution, inequality may undermine the very basis of democratic legitimacy (2014). Tomaskovic-Devey et al. (2014) estimate that financialization has had an overall negative impact on non-financial sector output, where the resulting falloff in employment was borne by core labour, and where senior corporate officers netted gains from compensation packages linked to capital income. If the net effect of financialization is merely to induce greater economic exposure to middle and low-income earners through debt incumbency and macroeconomic instability, an understanding of the factors driving this disproportionate capture of reward by top earners is therefore urgently needed.

This article examines the impact of financialization on top incomes, based on existing research into the dynamics and drivers of income inequality. It draws on literatures identifying the asymmetric balance of bargaining power between capital and labour as a key determinant of the distribution of economic reward, and on research into the embeddedness of economic growth within 'social structures of accumulation' comprising historically specific regulatory orders, modes of economic governance and orientations to redistribution and social protection. With the exception of Dunhaput (2015) who focuses on a different set of financialization and corporate governance related predictors, and Volscho and Kelly's (2012) and Hicks' (2014) studies of US top incomes, this study is among the first to examine in a panel context, the impact of financialization and financial regulation on the $1 \%$. Using panel models of 14 Organisation for Economic Co-operation and Development (OECD) countries from 1990 to 2010, it argues that financialization influences top incomes through two principal domains: (a) by altering the balance of bargaining power between capital and labour, and (b) through state regulatory controls and redistributive mechanisms. Interpreting these results within a regulation framework thus confronts certain limitations in Piketty's treatment of class relations and power asymmetries in his account of top income growth, whilst pointing 
towards specific policy domains through which institutional change may effect greater equality of outcome, beyond taxation alone.

\section{Financialization and income inequality}

Why focus on top incomes specifically? Studies of inequality to date have largely taken the personal income distribution as their key outcome, and this has indeed fostered the construction of a useful body of theory which relates overall inequality to stressors such as globalization, skill-biased wage premiums and collective bargaining capacity. Whilst others have begun to open up the class politics of inequality by taking a closer look at the share of GDP accruing to labour and capital (Kristal, 2010; Stockhammer, 2013; Flaherty and Ó Riain, 2015), they tend to obscure the internal composition of the 'capital' grouping somewhat, by relying on aggregate summaries of capital derived from national accounts. Isolating top earners from the personal distribution is thus particularly warranted in light of their interdependence with other components of the income distribution, where outcomes for one group may affect the other (Atkinson, 2007). This is not merely a 'functional' relationship where the personal distribution responds mechanically to increases in upper fractiles, and the financialization literature discussed below underscores the uniqueness of mechanisms of top income enhancement, as distinct from those which drive inequality across the distribution as a whole. In the context of financialization, we thus find that substantial monetary gains tend to centre on resource-endowed individuals at the top of the distribution. Conversely, research on the impact of financial managerialism on working conditions reinforces this notion of interdependence between income groupings, by suggesting that the remaining 'resource-poor' have suffered with greater debt burdens, and poorer working conditions (Tomaskovic-Devey and Lin, 2011).

The income composition of the $1 \%$ is also distinct from that of the wider income distribution, with greater shares of rentier and entrepreneurial income (Alvaredo et al., 2013). The diversity of their income streams aside from earned income alone thus points to their coherence as a distinct 'class', a dimension often neglected in analytical work which has tended to focus on the $1 \%$ as merely another indicator of income inequality, rather than a distinct social group. There is a growing realization however that top earners form not only a particular statistical fractile, but a distinct social group with unique mechanisms of reproduction (Roine and Waldenstrom, 2010, p. 300). Using individual and firm-level data for the USA, Kim et al. (2015) have shown how high pay diffused among CEOs through status competition, facilitated by social networks and peer group influence. This important individual mechanism operated within a wider context of structural change such as the growing use of stock options for compensation and the reduction of top marginal tax rates, both of which feature strongly in the financialization literature considered below. The 'functional interdependence' of this fractile grouping relative to the wider income distribution, and the mechanisms identified by Kim et al. (2015) suggest that financialization may play a particular role in top income accumulation, in a manner qualitatively and quantitatively different from that of other ranges of the personal income distribution.

The political urgency of unpacking the drivers of this group is evident even within social democracies with historically high levels of resilience to inequality such as Finland, which have seen substantial increases in their personal income inequality (Gini), driven strongly by rising top income shares (Jantti et al., 2010). There is also an important empirical issue concerning 
the omission of the $1 \%$ from studies of the personal income distribution. Given the substantial variance of the income shares of the $1 \%$ which account for up to $30 \%$ of the total income distribution, studies which exclude this (i.e. through underestimations of this groups associated with survey data) may offer a misleading account of the drivers of income inequality (Alvaredo et al., 2013). The following section thus reviews the current state of knowledge surrounding the domains of financialization-related income redistribution. It attempts to draw out mechanisms of association by linking various aspects of the general narrative of financialization to the concentration of top incomes, whilst identifying relevant indicators.

\subsection{Financialization and worker's collective bargaining power}

Close connections have been established between the rise of finance-driven capitalism and the falling share of GDP accruing to workers as pay (Stockhammer, 2009, 2012, 2013). This imbalance in the 'factor' distribution of income between capital and labour, which has risen consistently across capitalist democracies since the 1980s (Kristal, 2010), has allegedly created a disjuncture between economic performance and the spread of its financial rewards, which have disproportionately accrued to high earners (Atkinson, 2009). The pace of this disjuncture has been especially strong in the financial sector, where top compensation has surged relative to other sectors (Kus, 2012). Specific connections between financialization and top income movement may thus initially be established in two ways. A more direct route suggests that profiteering in core financial sector activities disproportionately benefitted top earners by delinking pay from performance-related indicators, and through the provision of market-based compensation packages linked to stock options (Thompson, 2013). A more abstract driver of top income growth may be identified in the growing literature on the relative bargaining power of capital and labour, and its role in income redistribution. Although typically treated separately, in reality these are two sides of the same coin, insofar as both are implicated not only in greater capture towards the top of the personal income curve, but in the consolidation of structural conditions reflecting a real shift in the capacity of institutions and actors to effect greater equality of outcome. Whilst the former is well represented in the financialization literature, the latter requires some contextualization in order to provide a clearer conceptual link to top income movement.

The period from the late 1970s to 2008 saw substantial growth in capital's share of GDP across the OECD, with a corresponding fall in labour's (Bentolia and Saint-Paul, 2003; Harrison, 2005; Ellis and Smith, 2007; Decreuse and Maarek, 2008; Kristal, 2010). As globalization and structural adjustment in the post-war era opened new markets for consumer goods, it also introduced wage competition as industrializing regions became attractive destinations for corporations seeking to cut their labour costs (Harrison, 2005). The 1970s-1980 also saw an increasing penetration of labour-saving technology into the labour process, public spending retrenchment, extensive labour market deregulation, and capital account liberalization under successive neoliberal governments. The result was a weakening of traditional labour protections, and the consolidation of policy regimes which would later underpin the growth of financial sectors within many capitalist democracies (Rueda and Pontusson, 2000; Jayadev, 2007). Under the influence of such stressors, capacities for collective solidarity were weakened as deindustrialization across the developed North eroded traditional bulwarks of unionism.

In tandem with this shift in capital's fortunes, how has financialization particularly enabled the wealthiest to increase their income share on foot of labour's growing structural powerlessness? The hypothesized intermediary role of relative bargaining power is readily 
assimilable to the financialization literature. Boyer was among the first to explore the distributional consequences of financialization, providing a theoretical link between the rise of financial markets and shareholder power, and the dynamics of income distribution in the post-Fordist era (Boyer, 2000). Accordingly, he identifies a 'reactive wage labour nexus' under finance-led growth, as a replacement for the comparatively stable social compacts of Fordism (Boyer, 2000, p. 117). This dual weakening of labour's capacity to extract its stable factor share, coupled with a shift in bargaining power from labour to firm is consistent with Thompson's model of financialized corporate strategies 'disconnected' from human capital concerns (Thompson, 2003, 2013). Under this 'shareholder value' regime, financial incomes such as dividends, interest payouts, and capital gains have risen whilst financial globalization has eroded workers share of economic rewards (Stockhammer, 2013).

Accordingly, CEO pay is now 262 times that of the average worker, with stock options comprising a sizeable proportion of compensation packages (Kus, 2012, p. 485). The corresponding rise in the financial sector's share of profits, coupled with strong growth in rentier incomes linked to ownership of financial assets, thus suggests a profound upward transfer effect related to the rise of the financial sector (Epstein and Power, 2003; Volscho and Kelly, 2012). Conversely for labour, as real wages remained stagnant during periods of finance-driven growth, falling wage shares stifled consumption demand, leading to the emergence in many developed countries of a debt-driven growth model where easy access to credit fuelled domestic demand (Stockhammer, 2012). Capitalizing on the same process which fuelled indebtedness, high earners leveraged greater returns by buying into securities, which together generated rising instability in the financial system, whilst decreasing the resilience of low-middle income earners to macroeconomic shocks (Guttman, 2008).

Empirical evidence linking financialization and inequality is substantial, and econometric analyses have already demonstrated the potential for higher capital shares of GDP to increase functional income inequality. When labour endowments are weak, higher capital shares appear to drive personal income inequality higher, and when labour's bargaining capacity is stronger (i.e. when labour's share of GDP increases), its effect on top quintile income is negative (Daudey and Garcia-Penalosa, 2007, p. 18). Similarly, Stockhammer (2013) found strong evidence linking financialization-related variables to an erosion of worker's share of GDP, results mirrored in Kus' (2012) analysis of its impact on post-tax Gini coefficients. On the basis of these observed connections between the factor and functional income distributions, it appears that the relative power resources of capital and labour may be central to understanding the rising capture of income by top earners. Furthermore, by omitting the mediating role of bargaining power (driven by strong financial sector performance since the 1990s), and its consequent erosion of worker's wage bargaining capacity, an important mechanism in the facilitation of top income capture may have been overlooked.

\subsection{Financialization as a social structure of accumulation}

There is little doubt that the capital-labour dynamic associated with the era of neoliberal financialization represents a distinct break from other historical epochs of capitalism (Kotz, 2003; Jessop, 2013). Locating the growth of top incomes within the realm of struggle between capital and labour over economic rewards in the labour market represents but one aspect of the politics of income distribution however. States and trans-national polities have equally underpinned this bargaining asymmetry through the policy measures and distributive mechanisms associated with deregulation and financial globalization. In this sense, regulation 
theory offers a useful framework for thinking through both the systemic underpinnings of inequality as captured by the concept of relative bargaining power, as well as the unique institutional and policy frameworks associated with the era of financialization. The assumption of the centrality of regulation forms the basis of the 'social structures of accumulation' school (SSA) which emphasizes the role of states in capital accumulation through their maintenance of institutions of law and private property, systems of financial exchange and governance, and labour markets (McDonough et al., 2010). The evolution of the various historical SSA's is typically treated sequentially. Following the demise of Atlantic Fordism with its emphasis on a demand-sustaining compromise between capital and labour, SSA theorists identified a successor in the form of a finance-based regime of accumulation, predicated on a disembedding of capital from regulatory constraints and a commodification of the social wage through cheap credit (Tabb, 2010).

Regulation thus provides a useful theoretical backdrop to the analysis of top income movement, as it deals with financialization not only as a specific regulatory order, but as a logic of capitalism inherently disposed towards rising inequality (van der Zwan, 2014, p. 106). While deregulation was instituted partly to address post oil-crisis stagflation, it instead ushered a shift from commercial to investment banking, and from loans to securities, disproportionately benefitting wealthy investors (Guttman and Plihon, 2008). These shifts were underpinned by policy measures including the US Monetary Control Act of 1980, later Financial Services Modernization Act of 1999 (Lin and Tomaskovic-Devey, 2013) and the European Second Banking Directive of 1989 (Guttman, 2008).

The structures of this regime of finance-driven accumulation are well-articulated within the financialization literature. The concept's insistence on real change in institutional structure is borne out by the disastrous impact of successive finance-driven crisis since the early 2000s, and recognition of the pervasive hand of the state in sustaining financial markets through taxation policy and regulation (van der Zwan, 2014). These new institutional and regulatory orders played a key role in facilitating top income capture, and the surge in capital gains and rentier income noted amongst industrialized countries throughout the 1990s was predicated on a number of regulatory shifts such as capital account openness, which increased capital mobility relative to labour since the 1990s, disproportionately raising capital returns (Epstein and Power, 2003; Jayadev, 2007). Growth in profits attributable to financial intermediation and interest income in the OECD was driven by anti-inflationary monetary policies which raised real interest rates leading to greater capital gains, and deregulation of the financial sector which enabled domestic innovation in financial instruments as well as the incorporation of overseas markets for financial products (Epstein and Power, 2003, pp. 234-235).

While many countries have seen cuts or stagnation in their capital gains and top income taxation rates (GINI, 2011, p. 93), reliance on regressive redistribution measures such as indirect consumption tax often does little to alter the balance of income around the median (Bermandi and Rueda, 2007). Piketty provides a compelling link between regulatory regimes and the politics of wage bargaining, suggesting that taxation played a key role in determining the capacity of top earners to leverage greater incomes. His analysis shows that top incomes correlate weakly with productivity, responding instead to lower marginal tax rates which encouraged executives to bid for higher compensation without the threat of losing their increases to the state (Piketty, 2014, pp. 508-512). Furthermore, there is worrying evidence that the redistributive capacity of some welfare states (the percentage reduction in Gini 
from market to net income) is falling even amongst social democracies such as Denmark which has dropped from $50 \%$ in 1995 , to $46 \%$ in 2010 (Solt, 2009). These observations suggest that top earners have not only managed to capitalize on the opportunities offered by deregulation, but to sidestep the absorption of their income by the redistributive mechanisms of the state.

Analyses have also shown how the impact of policy measures associated with financialization on top incomes was specifically channelled through domestic institutional structures, through the capacity of the wealthy to affect policy. Volscho and Kelly (2012) found strong evidence for the impact of institutional factors on the pre-tax income share of the top $1 \%$ in the USA since the late 1940s. Their analysis noted an asymmetry in the power resources of categorical income groups, where top income growth was affected first through the capacity of organized labour to influence the market distribution of income, and second through the capacity of states to redistribute through taxation policy and social transfers. It is therefore difficult to attribute the growth of top incomes throughout this time to market forces alone given the clear political history of the loosening of institutional constraints on financial innovation. Drawing on a regulationist-informed view of financialization thus provides us not only with a mechanism for linking regulatory politics to the material accumulation of specific interest groups, but with a ready source of indicators such as the spread of the tax burden between capital and labour, the capacity of the state to redistribute market income and the scope of financial sector regulation.

\section{Data and method}

The following analysis uses fixed effects (within) ordinary least squares (OLS) regression models which control for cross-unit heterogeneity, on a strongly balanced panel of 14 OECD countries from 1990 to 2010. This specification is appropriate in the presence of between-group inequalities, and when subject-specific confounding cannot be ruled out (Rabe-Hesketh and Skrondal, 2012). Our analysis incorporates countries and variables which are likely to display crosssectional and temporal dependence, given the close economic inter-relationships likely to exist between countries and regional polities under trade and financial globalization (Christophers, 2012). Similarly, controls such as trade openness and economic growth are likely to be correlated amongst units with close trading dependencies, who may experience common patterns of exposure to economic shocks (i.e. the recent financial crisis). To account for these issues, we use Driscoll-Kraay standard errors which are robust to heteroskedasticity, autocorrelation and cross-sectional dependence (Hoechle, 2007, p. 285).

Mindful of issues related to non-stationarity, Appendix A reports panel unit root diagnostics, and an additional set of tables comparing coefficients with models estimated in first differences is available as an online supplement. Given the robustness of the FE estimator with comparatively small values of $t$ (Woolridge, 2013, p. 472), and potential issues in a minority of specifications with missing values, the FE estimator is preferred. As a final robustness check, and to account both for temporal lags in the effect of independent variables on top incomes and the potential presence of endogenous predictors, we also include a full dynamic specification using the Arellano-Bond Generalized Method of Moments (GMM). These models include a lagged dependent variable, and all predictors are lagged by a period of one year. Across each of the three domains detailed below, variables are selected for inclusion in the GMM specification based on their substantive and statistical significance across previous models. Results in the dynamic specification are largely consistent with the fixed effects estimator. 
The dependent variable is the share of income accruing to the top $1 \%$, sourced from the World Top Incomes Database (WTID) (Alveredo et al., 2014). These data offer the advantage of using tax records to estimate top income shares, mitigating issues of underestimation often associated with national surveys. ${ }^{1}$ As the individual country series' adopt a common methodology, combining tax data-derived estimates of income with control totals for population and income, their cross country comparability is considerably enhanced (Atkinson and Sogaard, 2013 , p. 3). The various top incomes series' also follow comparable 'gross income' concepts which are incomes prior to allowable deductions such as interest, depreciation, pension and charitable contributions. They typically include income items such as salaries, wages, selfemployment income, business and farm income, dividends, rents and interest; fractiles are then estimated against a control total often derived from adjusted national accounts totals of personal income. Capital gains are treated according to country tax code definitions. Income jurisdictions, realized capital gains are assessed under a separate system of returns, whilst in countries such as Australia and the UK, certain gains are considered under regular income tax.

The exclusion of realized capital gains is generally preferred, as realizations of capital income are not typical 'flow' items but instead form a volatile component of income, with strong periodic variations dependent on stock prices. The USA offers a good illustration of this, as ' . . . capital gains are typically very lumpy (they are realized once every few years), so that ranking tax returns by income level including capital gains leads to artificially overestimate very top income levels' (Piketty and Saez, 2007, p. 195). Furthermore, including realized capital gains risks erroneously assigning individuals to top fractiles who only occupy their position at the time of their asset sale (Roine and Waldenstrom, 2010, p. 314). Most calculations include 'rentier' items such as dividends, interest, farm income and rents under their gross income definition however, with final income concepts typically comprising labour, capital (interest and dividends) and business income, less realized capital gains. The inclusion of these capital items thus allows us to align the dependent variable with the narrative of financialization-related mechanisms of inequality growth. These measurement issues are discussed in detail in the country chapters in Atkinson and Piketty (2007, 2010), and Appendix B summarizes measurement procedures for those countries discussed in these volumes. Finally, the reliability of pooling and the suitability of this series for modelling is further affirmed by the observation that this income series closely tracks other measures of personal income inequality such as the Gini/Atkinson coefficients and income percentile ratios. These observations suggest that factors often found to influence the bottom and mid-range of the income distribution may have similar effects at the top (Leigh, 2007), albeit through qualitatively different mechanisms as detailed above.

Inclusion of cases is determined by the availability of complete series from the WTID offering an added benefit, as the tax-derived income series of developed nations are typically more reliable than those of developing nations (Leigh, 2007, p. 621). Countries included in the following analysis are Australia, Denmark, Finland, France, Ireland, Italy, Japan, New Zealand, Norway, Spain, Sweden, Switzerland, UK and the USA. Models are specified according to the two principal domains which we suggest mediate the impact of financialization on top incomes.

1 Finland's top income estimates are derived from the Income Distribution Survey for post-2003 figures. Although the series relies on sample data, they are sourced from administrative registers of income, taxes and benefits. This is likely to avoid problems of access or 'opting out' which hinder conventional survey methodologies. 
As detailed above, the substantive and conceptual scope of these domains includes the bargaining capacity of high earners relative to labour (power resources), and the embedding of financialization in regulatory structures (social structures of accumulation). As both domains are embedded in bodies of formal theory with supporting econometric works, they offer not only a source of explanatory narrative, but specific control variables as elaborated below.

\subsection{Power resources and the capital-labour bargain}

Operational definitions, sources and summary statistics for all variables are provided in Tables 1 and 2. The first set of models assesses the impact of financialization on top income shares, controlling both for institutional protections associated with mitigating inequality, and the extent of labour's power resources. These specifications draw in particular on the work of Kus (2012) who notes the positive impact of financialization on personal income inequality net of bargaining controls such as unionization, trade openness and government spending. These parameters also attempt to capture a particular asymmetry in power resources linked to bargaining capacity identified by Piketty (2014), which has underpinned the 'property space' of top earners incentives in financialized economies. Sectoral models of the impact of financialization on senior compensation have confirmed this growing asymmetry, by noting strong top income growth linked to financialization, coupled with a negative effect of unionization (Lin and Tomaskovic-Devey 2013, p. 1308). Consistent with existing studies which have modelled the impact of financialization on the personal and factor distribution of income (Kus, 2012; Volscho and Kelly, 2012; Stockhammer, 2013), we include trade union density from Visser's ICTWSS database (2013), government consumption as a percentage of GDP from the Penn World Table and the KOF index of economic globalization compiled from data on trade flows, and trade restrictions (Dreher, 2006). This index combines economic integration measures of actual flows (i.e. foreign direct investment and income payments to foreign nationals), with measures of restrictions (i.e. import barriers and tariff rates). Eight measures are rescaled $(0-100)$ to produce a composite index of economic globalization (Dreher et al., 2008). Whilst this measure captures a wide range of economic integration factors, we also include a direct measure of domestic trade openness from the Penn World Table, calculated as the percentage of combined imports and exports over GDP. To these are added unemployment, and female labour force participation rates drawn from the OECD Structural Analysis (STAN) statistics, as measures of cyclical economic downturn (Volscho and Kelly, 2012), and changing labour market composition, respectively. Economic growth performed weakly in all specifications and was therefore excluded, although all coefficients are robust to its inclusion. Furthermore, as these models deal largely with labour market-related variables, the effect of weak economic performance is likely to be registered through unemployment.

Drawing on literatures which theorize the channelling of financialization through the workplace through intensive, equity-oriented HR practices (Thompson, 2003; Cushen and Thompson, 2013), we include a measure of the market capitalization of listed firms, in order to capture the effect of firm participation and diversification into financial activities. Given the suggested importance of credit in sustaining consumption under real wage stagnation, and the issue of rising productivity capture by capital highlighted by the International Labour Organization (2013), we include a measure of the volume of domestic credit issued by banks to the private sector as an indicator of the growing importance of credit.

In order to capture the importance of finance relative to other economic sectors, we include the gross operating surplus of Finance, Insurance and Real Estate as a percentage of total 
Table 1. Variable definitions and sources

\begin{tabular}{|c|c|c|}
\hline Variable & Operational definition & Source \\
\hline Top $1 \%$ income share & $\begin{array}{l}\text { Share of income accruing to top } 1 \% \text { of earners } \\
\text { based on taxation data. }\end{array}$ & $\begin{array}{l}\text { WTID (see } \\
\text { Appendix B) }\end{array}$ \\
\hline Government consumption & $\begin{array}{l}\text { National accounts government consumption as } \\
\% \text { of Gross Domestic Product (sum of } \\
\text { collective consumption of government } \\
\text { including public good activities, health and } \\
\text { education). }\end{array}$ & $\begin{array}{l}\text { Penn World } \\
\text { Table (Heston } \\
\text { et al., 2012) }\end{array}$ \\
\hline Union density & $\begin{array}{l}\text { Net union membership as \% of wage and salary } \\
\text { earners in employment. }\end{array}$ & Visser (2013) \\
\hline Economic globalization & $\begin{array}{l}\text { Weighted percentage index comprising FDI } \\
\text { stocks, portfolio investment, trade and } \\
\text { income payments to foreign nationals. }\end{array}$ & Dreher (2006) \\
\hline Trade openness & $\begin{array}{l}\text { Exports and imports as \% share of current-price } \\
\text { Gross Domestic Product. }\end{array}$ & $\begin{array}{l}\text { Penn World } \\
\text { Table (Heston } \\
\text { et al., 2012) }\end{array}$ \\
\hline Unemployment & $\begin{array}{l}\text { Number of unemployed persons as } \% \text { total } \\
\text { labour force (unemployed + those in paid or } \\
\text { self-employment). }\end{array}$ & OECD Database \\
\hline $\begin{array}{l}\text { Female labour force } \\
\text { participation }\end{array}$ & $\begin{array}{l}\text { Females participating in labour force as } \% \text { total } \\
\text { female population. }\end{array}$ & OECD Database \\
\hline $\begin{array}{l}\text { Market capitalization of listed } \\
\text { firms (\% GDP) }\end{array}$ & $\begin{array}{c}\text { Share price times number of shares outstanding } \\
\text { of exchange-listed domestic companies, as } \\
\% \text { of GDP (Standard and Poor's data). }\end{array}$ & $\begin{array}{l}\text { World Bank } \\
\text { Databank }\end{array}$ \\
\hline Private sector credit ( $\%$ GDP) & $\begin{array}{l}\text { Loans, securities, trade credits provided to } \\
\text { private sector by financial corporations } \\
\text { (monetary authorities and deposit banks), as } \\
\% \text { of GDP (IMF data). }\end{array}$ & $\begin{array}{l}\text { World Bank } \\
\text { Databank }\end{array}$ \\
\hline $\begin{array}{c}\text { Finance, Insurance and Real } \\
\text { Estate Gross Operating } \\
\text { Surplus (\% all sectors) }\end{array}$ & $\begin{array}{l}\text { Gross Operating Surplus on financial sector } \\
\text { production activities as \% of all sectors, } \\
\text { from National Accounts data. }\end{array}$ & OECD STAN \\
\hline $\begin{array}{l}\text { Labour's share of Gross } \\
\text { National Income }\end{array}$ & $\begin{array}{l}\text { Compensation of employees + self-employed } \\
\text { income (nominal compensation per } \\
\text { employee * self-employed persons) as \% of } \\
\text { GDP. }\end{array}$ & AMECO \\
\hline Financial globalization (log) & $\begin{array}{l}\text { Log of external assets and liabilities (sum of } \\
\text { portfolio investment including equity and } \\
\text { debt securities, foreign direct investment, } \\
\text { debt instruments, financial derivatives and } \\
\text { reserves) as \% of GDP. }\end{array}$ & $\begin{array}{l}\text { Lane and } \\
\text { Milesi-ferretti } \\
\text { (2007) }\end{array}$ \\
\hline $\begin{array}{l}\text { Economic growth (real GDP } \\
\text { \% yearly change) }\end{array}$ & $\%$ Annual change in real GDP & $\begin{array}{l}\text { Penn World } \\
\text { Table (Heston } \\
\text { et al., 2012) }\end{array}$ \\
\hline $\begin{array}{l}\text { Capital taxation (\% total } \\
\text { tax burden) }\end{array}$ & $\begin{array}{l}\text { Levies on capital transfers or assets as } \% \text { total } \\
\text { tax burden }\end{array}$ & AMECO \\
\hline
\end{tabular}


Table 1. Continued

\begin{tabular}{|c|c|c|}
\hline Variable & Operational definition & Source \\
\hline $\begin{array}{l}\text { Indirect taxation (\% total tax } \\
\text { burden) }\end{array}$ & $\begin{array}{l}\text { Taxes on goods and services as \% total tax } \\
\text { burden }\end{array}$ & AMECO \\
\hline Net income inequality (Gini) & $\begin{array}{l}\text { Standardized post-tax and transfer Gini income } \\
\text { inequality, imputed from Luxembourg } \\
\text { Income Study data }\end{array}$ & Solt (2009) \\
\hline $\begin{array}{l}\text { Extent of banking sector } \\
\text { liberalization }\end{array}$ & $\begin{array}{l}\text { 6-point scale of presence/absence coded } \\
\text { conditions: restrictions on opening of } \\
\text { foreign banks, government permission of } \\
\text { competition in domestic banking market, } \\
\text { restrictions on branching, limits on bank } \\
\text { activities }(0=\text { fully repressed, } 5=\text { fully } \\
\text { liberalized). }\end{array}$ & Abiad et al. (2008) \\
\hline $\begin{array}{l}\text { Extent of banking sector } \\
\text { supervision }\end{array}$ & $\begin{array}{l}\text { 7-point scale of presence-absence coded } \\
\text { conditions: country adoption of Basle } \\
\text { capital adequacy ratio, independence of } \\
\text { supervisory agency, presence of onsite } \\
\text { examinations and regulatory coverage of all } \\
\text { financial institutions ( } 0=\text { Not Regulated, } \\
6=\text { Highly Regulated). }\end{array}$ & Abiad et al. (2008) \\
\hline Financial reform index & $\begin{array}{l}\text { Normalized sum of financial reform measures: } \\
\text { credit controls, pro-competition measures, } \\
\text { banking supervision, privatization, } \\
\text { international capital flows and security } \\
\text { markets (greater value = greater extent of } \\
\text { reform). }\end{array}$ & Abiad et al. (2008) \\
\hline Top $0.1 \%$ income share & $\begin{array}{l}\text { Share of income accruing to top } 0.1 \% \text { of earners } \\
\text { based on taxation data. }\end{array}$ & $\begin{array}{l}\text { WTID (see } \\
\text { Appendix B) }\end{array}$ \\
\hline
\end{tabular}

sectoral gross operating surplus taken from the OECD's Structural Analysis database. While this is a preferable measure of financialization since it captures the growing contribution of finance relative to other economic sectors (Krippner, 2011), its coverage ranges from 1990 to 2008. Finally, we include the share of Gross National Income accruing to workers as compensation (labour's share), as a core measure of the bargaining power of labour relative to capital. Studies have shown the negative impact of labour's share on personal income inequality (Gini), stressing the long-term importance of strong collective bargaining in sustaining greater rewards for labour, and a more equitable distribution of income (Daudey and Garcia-Penalosa, 2007; Stockhammer, 2013). These studies offer strong justification for including labour's share as an intermediary between the determination of an economy-wide income pool, and the politics of its personal distribution (Atkinson, 2009).

\subsection{Financial regulation and redistribution}

The second set of models examines the impact of financial regulation and redistributive capacity. These models address more pointedly the institutional structures underpinning asymmetric bargaining capacity, by testing the extent to which taxation and redistribute capacity 
Table 2. Summary statistics

\begin{tabular}{lccccc}
\hline Variable & Mean & SD & Minimum & Maximum & Obs \\
\hline Top 1\% income share & 8.88 & 2.74 & 4.37 & 18.33 & 280 \\
Government consumption & 6.80 & 1.10 & 4.08 & 9.46 & 280 \\
Union density & 37.46 & 23.31 & 7.6 & 83.9 & 280 \\
Economic globalization & 75.03 & 12.12 & 42.1 & 97.01 & 280 \\
Trade openness & 62.87 & 31.65 & 16.01 & 183.29 & 280 \\
Unemployment & 7.41 & 3.96 & .47 & 24.17 & 280 \\
Female labour force participation & 52.76 & 8.05 & 33.2 & 64.2 & 280 \\
Market capitalization of listed firms (\% GDP) & 81.72 & 56.16 & 10.19 & 317.03 & 280 \\
Private sector credit (\% GDP) & 115.47 & 49.5 & 30.77 & 232.1 & 280 \\
Finance, Insurance and Real Estate Gross Operating & 31.42 & 7.05 & 16.59 & 47.36 & 247 \\
$\quad$ Surplus (\% all sectors) & & & & & \\
Labour's share of Gross National Income & 58.68 & 5.01 & 43.82 & 70.46 & 280 \\
Financial globalization (log) & 5.41 & 0.70 & 4.16 & 7.54 & 210 \\
Economic growth (real GDP \% yearly change) & 4.6 & 3.37 & -10.24 & 17.6 & 280 \\
Capital taxation (\% total tax burden) & 0.75 & 0.57 & 0.00 & 4.56 & 244 \\
Indirect taxation (\% total tax burden) & 31.82 & 4.56 & 20.28 & 41.9 & 244 \\
Net income inequality (Gini) & 29.37 & 4.48 & 20.75 & 37.84 & 280 \\
Extent of banking sector liberalization & - & - & 1 & 3 & 224 \\
Extent of banking sector supervision & - & - & 0 & 3 & 224 \\
Financial reform index & 0.91 & 0.09 & 0.52 & 1 & 224 \\
Top 0.1\% income share & 2.91 & 1.55 & 0.93 & 8.25 & 216 \\
\hline
\end{tabular}

may have augmented top income growth, by impacting the ability of top earners to realize higher income levels (Piketty, 2014). According to Piketty, relaxed top income taxation and wider financial regulation - theorized above as embedded in a specific historical regulatory logic-played a key role in spurring inter-actor wage competition since the 1980s. These models control for government consumption, union density and economic globalization, as well as market capitalization as a base measure of domestic financialization. We also include economic growth measured as the yearly percentage change in real GDP taken from the Penn World Table. This variable controls for periods of economic volatility, whilst testing for transfer effects linked to stronger economic performance (Kus, 2012; Volscho and Kelly, 2012). Models include financial globalization, measured as the log of external assets and liabilities over GDP (ILO, 2013; Stockhammer, 2013) in order to capture the dependence of domestic financialized profitability on international expansion (Christophers, 2012). The data on financial globalization are taken from Lane and Milesi-Ferretti (2007), and their coverage extends from 1990 to 2004. In light of their limited coverage, inclusion of this variable is limited to the first model in order to capture its unique effect as a component of financialization, and to maximize panel coverage for subsequent models.

In order to assess whether top income growth has proceeded independent of domestic taxation measures, and to assess the distributional consequences of different taxation streams, we include the extent of capital and indirect taxation as a percentage of the total tax take, sourced from the European Commission's Annual Macro-Economic Database (AMECO). This set of models also includes a measure of post-tax and transfer income inequality taken from Solt (2009), in order to assess the relationship between underlying personal income inequality 
rates, and concentrations within upper percentiles. Given the greater redistributive capacities associated with more social democratic transfer systems, we should expect greater levels of personal income inequality across the personal distribution to influence top percentile accumulation (Atkinson et al., 2010, p. 706). To account for potential endogeneity, a re-specified model using the income share of the top $0.1 \%$ is available as an online supplement, although results in the GMM specification are similar in direction. The political basis of redistributive capacity is further emphasized by research showing how social expenditure, capital taxation rates and top income growth are often dependent on partisan incumbency, and their disposition to greater or lesser degrees of regulation and social transfer (Castles and Obinger, 2007; Volscho and Kelly, 2012). Finally, to assess the effect of financial sector regulation, we include measures of the extent of banking sector liberalization, the extent of banking sector supervision as well as a standardized index of financial sector reform, all taken from Abiad et al. (2008). Full details of their operational definitions and direction of scoring are provided in Table 2.

\section{Results}

\subsection{Power resources and the capital-labour bargain}

The labour market-bargaining context of inequality observed in existing studies thus appears to hold in relation to top incomes, in light of consistency in the magnitude and direction of controls across all specification (Table 3 ). Institutional protections such as government consumption and unionization compress top income accumulation, whilst trade openness and economic globalization appear to benefit top incomes, consistent with studies of the impact of globalization on capital shares which link increasing capital power to technologically driven productivity capture, innovation in financial instruments, capital account openness and trade deregulation (Harrison, 2005; Jayadev, 2007). Unemployment, which captures both cyclical economic downturns and the corresponding structural weakness of labour, displays positive association with top incomes across all specifications. This is unsurprising given the comparative ease with which high earners are able to weather economic downturns through reliance on alternative 'unearned' income streams linked to financial instruments, an effect mirrored in later specifications which show positive effects linked to economic growth (Volscho and Kelly, 2012). The accession of women to the labour force, a condition associated with accession to low-security, low-skill occupations (Kus, 2012) is also unstable across specifications and non-significant in the full bargaining model, suggesting these mechanisms may bear more relevance to the wider personal income distribution.

The progressive inclusion of different components of financialization allows us to examine more clearly their effects, in tandem with underlying labour market conditions. The positive effect of finance-related variables supports our assertion that financialization has driven top income growth through bargaining asymmetry, both by stifling real incomes through demandsustaining debt servicing, and weakening bargaining capacity under decentralized industrial relations. In the literature, the growth of debt markets plays an important role as an additional channel for the enrichment of top earners through securitization, aided by innovation in financial instruments linked to increasing firm involvement in financial markets. The effects of both market capitalization and domestic credit volume are weak relative to stressors such as unemployment and economic globalization however, with the latter non-significant. The weaker effect of debt is curious, considering that rising debt has been linked both to 
Table 3. Power resources and the capital-labour bargain

\begin{tabular}{|c|c|c|c|c|c|c|}
\hline & \multicolumn{6}{|c|}{ Top $1 \%$ income share } \\
\hline & 1 & 2 & 3 & 4 & 5 & GMM \\
\hline Top $1 \%_{(t-1)}$ & - & - & - & - & - & $\begin{array}{l}0.256^{* * *} \\
(2.63)\end{array}$ \\
\hline Government consumption & $\begin{array}{l}-0.530 * * \\
(-2.40)\end{array}$ & $\begin{array}{l}-0.340 \\
(-1.66)\end{array}$ & $\begin{array}{l}-0.619 * * \\
(-2.79)\end{array}$ & $\begin{array}{l}-0.809 * * \\
(-2.84)\end{array}$ & $\begin{array}{l}-0.551 * * \\
(-2.84)\end{array}$ & $\begin{array}{l}-0.100 \\
(-1.14)\end{array}$ \\
\hline Unionization & $\begin{array}{l}-0.059 * * \\
(-2.18)\end{array}$ & $\begin{array}{l}-0.081 * * \\
(-2.59)\end{array}$ & $\begin{array}{l}-0.047^{*} \\
(-1.77)\end{array}$ & $\begin{array}{l}-0.016 \\
(-0.65)\end{array}$ & $\begin{array}{l}-0.032 \\
(-1.43)\end{array}$ & $\begin{array}{l}-0.063^{* *} \\
(-2.02)\end{array}$ \\
\hline Economic Globalization & $\begin{array}{l}0.054 * * * \\
(3.15)\end{array}$ & $\begin{array}{l}0.010 \\
(0.57)\end{array}$ & $\begin{array}{l}0.051 * * * \\
(2.94)\end{array}$ & $\begin{array}{l}0.038 \\
(1.06)\end{array}$ & $\begin{array}{l}-0.020 \\
(-0.51)\end{array}$ & $\begin{array}{l}0.059 \\
(1.60)\end{array}$ \\
\hline Trade openness & $\begin{array}{l}0.017^{* * *} \\
(2.66)\end{array}$ & $\begin{array}{l}0.009 \\
(0.87)\end{array}$ & $\begin{array}{l}0.016 * * \\
(2.58)\end{array}$ & $\begin{array}{l}0.021 * * * \\
(4.23)\end{array}$ & $\begin{array}{l}0.006 \\
(0.74)\end{array}$ & $\begin{array}{l}-012 \\
(-0.86)\end{array}$ \\
\hline Unemployment & $\begin{array}{l}0.087^{* * * *} \\
(3.09)\end{array}$ & $\begin{array}{l}0.076^{* * *} \\
(3.42)\end{array}$ & $\begin{array}{l}0.093 * * * * \\
(2.97)\end{array}$ & $\begin{array}{l}0.074 * * \\
(2.10)\end{array}$ & $\begin{array}{l}0.059 * \\
(1.91)\end{array}$ & $\begin{array}{l}0.057^{*} \\
(1.93)\end{array}$ \\
\hline Female labour force & $\begin{array}{l}0.092^{* *} \\
(2.76)\end{array}$ & $\begin{array}{l}0.081 * * \\
(2.71)\end{array}$ & $\begin{array}{l}0.078 * * \\
(2.60)\end{array}$ & $\begin{array}{l}-0.014 \\
(-0.21)\end{array}$ & $\begin{array}{l}-0.001 \\
(0.03)\end{array}$ & - \\
\hline Market capitalization & - & $\begin{array}{l}0.011 * * * \\
(6.34)\end{array}$ & - & - & - & - \\
\hline Domestic credit volume & - & - & $\begin{array}{l}0.004 \\
(1.54)\end{array}$ & - & - & - \\
\hline $\begin{array}{l}\text { FIRE gross operating } \\
\text { surplus }\end{array}$ & - & - & - & $\begin{array}{l}0.185 * * * \\
(3.24)\end{array}$ & $\begin{array}{l}0.161 * * * \\
(4.02)\end{array}$ & $\begin{array}{l}0.116^{* * * *} \\
(3.53)\end{array}$ \\
\hline Labour's share of GNI & - & - & - & - & $\begin{array}{l}-0.207 * * * \\
(-4.01)\end{array}$ & $\begin{array}{l}-0.079 * * * \\
(-3.77)\end{array}$ \\
\hline C & $\begin{array}{l}4.053 * * \\
(2.12)\end{array}$ & $\begin{array}{l}7.149 * * * \\
(3.27)\end{array}$ & $\begin{array}{l}4.848 * * \\
(2.34)\end{array}$ & $\begin{array}{l}5.338 \\
(0.97)\end{array}$ & $\begin{array}{l}21.673 * * * \\
(2.87)\end{array}$ & $\begin{array}{l}6.710 * * \\
(2.29)\end{array}$ \\
\hline$P$-value $\left(F / \mathrm{chi}^{2}\right)$ & 0.000 & 0.000 & 0.000 & 0.000 & 0.000 & 0.000 \\
\hline Obs & 272 & 270 & 267 & 241 & 241 & 218 \\
\hline Groups & 14 & 14 & 14 & 14 & 14 & 14 \\
\hline$R^{2}$ & 0.852 & 0.862 & 0.855 & 0.869 & 0.890 & - \\
\hline
\end{tabular}

$* 10 \% ; * 5 \% ; * * 0.01 \%$.

median income stagnation, and the substantial rise in publicly traded debt servicing agencies which would suggest a stronger effect (Kus, 2013a). This finding likely reflects Kus' analysis of the moderating effects of debt, which shored up consumption and moderated personal income inequality (Kus, 2013b).

The mechanism of association between top incomes and market capitalization is perhaps easier to establish, although its detected effect remains substantively small. As the 'disconnected capitalism' thesis is predicted on a divergence of corporate strategies towards share price and dividends, the corresponding delinking of executive pay from underlying performances indices likely underpins the strong growth of top managerial incomes relative to median wage earning (Lin and Tomaskovic-Devey, 2013). High-earning hedge fund managers now routinely earn over a billion dollars per year (the top 50 of whom are all male), whilst CEO earnings including salary bonus and stock option, have been rising since 2010, reaching 
an average of 10.5 million dollars in 2012 (Forbes, 2012). This is despite rising OECD market income inequality and increases of up to 8 percentage points in relative income inequality in countries such as Ireland since the onset of the financial crisis (OECD, 2014).

These discrete elements of the financialization narrative, and their embedding within broader logics of economic action, may be better understood through a more fundamental indicator-that of the relative importance of the financial sector. This variable forms a crucial context to the shifting power resources of economic actors, and its importance is evident in the consistent positive effect of FIRE sector operating surplus in our models. The outpacing of FIRE sector profits relative to other economic sectors reflects a fundamental shift in the generation of profits away from commodities and trade towards financial channels, a process which saw widespread dependence of non-financial industries on financial income streams as a profit subsidy (Krippner, 2005). Whilst the scale of this shift in the structure of profit has long been recognized as a key indicator of the conceptual validity of financialization, it also played a key role in reshaping power relations between interest groups within economic sectors. More general works on the distributional consequences of financial sector expansion particularly stress its effect on top-tier income capture, through the use of non-indexed performance bonuses and stock options (de Serres et al., 2002). As reflected in sectoral-level work on top compensation, the relative weight of financial to business receipts hastened a 'decoupling' of surplus generation from production, enhancing executive compensation while excluding the wider workforce from wage-setting as resources were steadily reallocated away from core production (Lin and Tomaskovic-Devey, 2013, p. 1294). The consistency of our FIRE variable thus generalizes this important structural precondition of bargaining asymmetry to the wider pool of advanced democracies.

The distributional consequences of the growing weight of the FIRE sector in economic life are further reflected in our findings concerning the effect of labour's share. Consistent with models of the relationship between the factor and personal income distribution, we find a greater share of labour in Gross National Income to be associated with a reduction in top income shares. Capital income growth has been explained with reference to the rise of growth strategies incorporating capital account deregulation (Jayadev, 2007) which are typically investment-oriented. As a result, greater shares of capital in national income have been associated with greater overall income inequality (Daudey and Garcia-Panalosa, 2007). The above results suggest that this relationship holds net of underlying bargaining controls, and of the sectoral importance of finance. Furthermore, it strongly affirms Atkinson's (2009) suggestion of giving greater attention to the intermediary effects of factor shares as a meaningful moderator of the personal income distribution. The balance of labour's share appears to matter not only as a definitional measure of the setting of an economy-wide income pool as per Atkinson, but also as a measure of the capacity of labour to effect greater income capture. All specifications thus point towards a strong asymmetry in bargaining capacity reflected both in the explanatory and conceptual literatures on finance-driven inequality.

\subsection{Financial regulation and redistribution}

The second set of models retains relevant controls from the power resources specification, namely government consumption, unionization and economic globalization, in order to include institutional power resources as a context for formal regulation. To these are added economic growth, both as a test of transfer effects linked to stronger economic performance 
Table 4. Financial regulation and redistribution

\begin{tabular}{|c|c|c|c|c|c|}
\hline & \multicolumn{5}{|c|}{ Top $1 \%$ income share } \\
\hline & 1 & 2 & 3 & 4 & GMM \\
\hline Top $1 \%_{(t-1)}$ & - & - & - & - & $\begin{array}{l}0.278 \\
(1.59)\end{array}$ \\
\hline Government consumption & $\begin{array}{l}-0.099 \\
(-0.78)\end{array}$ & $\begin{array}{l}-0.009 \\
(-0.07)\end{array}$ & $\begin{array}{l}-0.517 * * \\
(-2.57)\end{array}$ & $\begin{array}{l}-0.593^{* *} \\
(-2.79)\end{array}$ & $\begin{array}{l}0.051 \\
(0.27)\end{array}$ \\
\hline Unionization & $\begin{array}{l}-0.058^{*} \\
(-2.14)\end{array}$ & $\begin{array}{l}-0.204 * * * \\
(-7.26)\end{array}$ & $\begin{array}{l}-0.045 \\
(-1.20)\end{array}$ & $\begin{array}{l}-0.047 \\
(-1.20)\end{array}$ & $\begin{array}{l}-0.150^{* *} \\
(-2.57)\end{array}$ \\
\hline Economic Globalization & $\begin{array}{l}-0.042 * \\
(-2.06)\end{array}$ & $\begin{array}{l}0.031 \\
(1.34)\end{array}$ & $\begin{array}{l}-0.011 \\
(-0.33)\end{array}$ & $\begin{array}{l}-0.048 \\
(-1.03)\end{array}$ & - \\
\hline Economic growth & $\begin{array}{l}0.059 * * \\
(2.31)\end{array}$ & $\begin{array}{l}0.029 \\
(1.24)\end{array}$ & $\begin{array}{l}0.063 \\
(1.46)\end{array}$ & $\begin{array}{l}0.070 \\
(1.59)\end{array}$ & - \\
\hline Market capitalization & $\begin{array}{l}0.008^{* * *} \\
(4.09)\end{array}$ & $\begin{array}{l}0.009^{* * * *} \\
(8.50)\end{array}$ & $\begin{array}{l}0.011^{* * *} \\
(6.99)\end{array}$ & $\begin{array}{l}0.012^{* * * *} \\
(7.25)\end{array}$ & $\begin{array}{l}0.005^{* * *} \\
(2.64)\end{array}$ \\
\hline Log financial globalization (1990-2004) & $\begin{array}{l}1.528^{* * *} \\
(4.47)\end{array}$ & - & - & - & - \\
\hline Capital taxation & - & $\begin{array}{l}-0.179^{* *} \\
(-2.61)\end{array}$ & - & - & $\begin{array}{l}-0.017 \\
(-0.40)\end{array}$ \\
\hline Indirect taxation & - & $\begin{array}{l}-0.169^{* * *} \\
(-4.37)\end{array}$ & - & - & - \\
\hline Post-tax personal income inequality & - & $\begin{array}{l}0.238^{* * * *} \\
(3.27)\end{array}$ & - & - & $\begin{array}{l}0.191 \\
(1.02)\end{array}$ \\
\hline $\begin{array}{l}\text { Extent of banking sector liberalization } \\
\qquad(90-05)\end{array}$ & - & - & $\begin{array}{l}0.546^{* * *} \\
(2.28)\end{array}$ & - & - \\
\hline Extent of banking supervision (90-05) & - & - & $\begin{array}{l}0.393^{* *} \\
(2.59)\end{array}$ & - & - \\
\hline Financial reform index $(90-05)$ & - & - & - & $\begin{array}{l}0.229^{*} \\
(2.10)\end{array}$ & $\begin{array}{l}0.237^{* *} \\
(1.84)\end{array}$ \\
\hline C & $\begin{array}{l}5.431^{* * *} \\
(3.05)\end{array}$ & $\begin{array}{l}12.531^{* * *} \\
(3.51)\end{array}$ & $\begin{array}{l}12.950^{* * *} \\
(3.87)\end{array}$ & $\begin{array}{l}12.411 * * * \\
(4.61)\end{array}$ & $\begin{array}{l}1.878 \\
(0.44)\end{array}$ \\
\hline$P$-value $\left(F / \mathrm{chi}^{2}\right)$ & 0.000 & 0.000 & 0.000 & 0.000 & 0.000 \\
\hline Obs & 200 & 222 & 214 & 200 & 158 \\
\hline Groups & 14 & 12 & 14 & 14 & 12 \\
\hline$R^{2}$ & 0.915 & 0.905 & 0.872 & 0.875 & - \\
\hline
\end{tabular}

$* 10 \% ; * 5 \% ; * * 0.01 \%$.

(Volscho and Kelly, 2012), and as a precondition of state redistributive capacity linked to fiscal policy, which is likely to be responsive to underlying economic performance. As financial market engagement provides a theoretical link between the power resources of top earners vis-à-vis formal regulatory regimes, its consistency across both specifications net of underlying controls is noteworthy. Similar to Stockhammer (2013), we find a particularly strong effect for financial globalization net of other controls (Table 4). Given that the general weakening of median income associated with globalization is a standard condition of bargaining models of income distribution, it is unsurprising that this should also profoundly influence top incomes. 
This component of the globalization of finance may also be linked theoretically to the mechanism elaborated for market capitalization, where the outward focus of firms and inter-trading of financial instruments forms an integral component of the equity-oriented regime of corporate governance. Instrument innovation also plays a central role in Piketty's model of divergent economic growth and capital returns as a driver of wealth concentration, where the diversity of capital gains sources outstrips regulatory capacity. Together, both market capitalization and financial globalization have been associated with growing capital mobility, and a diversification of within-firm income streams, both of which appear to substantially augment the share of the top $1 \%$. In a broader sense, financial globalization should also capture the 'leveraging' effects of global finance. This has consistently been identified as a factor which raised the pre-crisis exposure of national polities to volatile financial markets, whilst also increasing the global scale of profiteering, as securitization and deregulation both conspired to erode the domestic limits of financial activity (Guttman, 2008; Tabb, 2010).

Specification two confirms something of the relationship between different components of the overall income distribution identified in our original bargaining models. Both the factor and personal distribution of income appear to track closely the shares of the top $1 \%$, with greater post-tax and transfer personal income inequality associated with higher shares of income for the top $1 \%$. Together, these measures construct a clearer overall picture of the inter-relationship between different aspects of the income distribution and top income capture, where the rise of the rich appears closely connected both to their volume of capital share in GNI, and weaker state redistributive capacity (personal income inequality). Higher capital taxes are predictably associated with lower top income shares, reflecting the likely dependence of this cohort on interest-bearing income. The effect of higher capital taxation may work either by conditioning of investor behaviour towards greater consumption, or by direct redistribution through social transfers (Volscho and Kelly, 2012, p. 694). The negative direction of indirect taxation is curious, considering greater reliance on consumption taxes is typically associated with regressive effects on inequality, where poorer households often bear the brunt of such increases. Although the distributive effect of various taxation streams depends on underlying consumption habits, luxury goods comprise a small proportion of the overall indirect taxation take, with the majority of consumption taxes levied on general goods (Bermandi and Rueda, 2007). Although results point strongly towards the efficacy of capital taxation and state distributive capacity as factors mitigating top income capture, further investigation is clearly needed into the composition of the tax take in terms of the spread and general cost of goods and services included.

Banking sector liberalization, banking sector supervision and financial reform are all associated with growth in top income shares. The finding that all should contribute to top income growth is explicable in terms of the content of the measures, and of the general logic of financial sector liberalization and supervision which accompanied financialization in advanced democracies. First, our banking sector variable is likely capturing the emergent effects of firmlevel liberalization, whereby restrictions on foreign competition in the banking sector, and on the range of permissible activities of banks was substantially relaxed over the timespan of our models. This formed an important precondition of the financial crisis, whereby the commercial banking sector sought to diversify its income streams in a competitive global market through greater reliance on leveraged financial instruments (Ó Riain, 2014, p. 143). This expansion was both facilitated and underpinned by a specific logic of 'light-touch' regulation which was embedded throughout the OECD through policy measures such as the repeal of 
the Glass-Steagall Act in the USA (Lin and Tomaskovic-Devey, 2013), global implementation of revisions to the Basel Accord (Guttman and Plihon, 2008) and the harmonization of fiscal rules and monetary policy under the provisions of the European Monetary Union (conditions captured broadly by our latter two variables). These institutional diversifications and policy measures have been shown not only to increase the volume of exposure of the financial system to high-yield capital markets, but also to drive welfare state retrenchment and weaken domestic labour movements, thus driving income inequality higher (Beckfield, 2006, 2009). In the post-crisis years it has also become clear that the pace of supervision and financial reform were insufficient to keep up with the growing complexity of financial instruments. This combination of banking liberalization and weak governance thus appears to have sustained a potent mechanism for top income gains by substantially enhancing the scope of rentier income streams, which form a key element in the income composition of top fractiles (Alvaredo et al., 2013, p. 12).

Further empirical indication is thus given to the process of disembedding described by Jessop (2013), where the institutional fixes of post-Fordist accumulation are predicted on political measures geared towards loosening constraints on financial capital. These measures have a clear political history through policies such as the Basel accord, which triggered widespread use of securitization by financial institutions in an attempt to circumvent its capital adequacy conditions (Guttman, 2008). Coupled with the recorded weakening in labour's share (Kristal, 2010) and growth in personal income inequality particularly since the financial crisis (OECD, 2014), the above results underline a class-based bargaining model of accumulation, where the political control of capital and its regulation have generated uneven advantage with a clear class gradient (Lin and Tomaskovic-Devey, 2013). Whilst our coefficients on taxation, redistributive capacity and financial globalization affirm the role of income-related social policy in tandem with financialization, there is clearly a broader politics of distribution at work, as revealed by the consistent direction and magnitude of institutional protections and stressors in all specifications. The political basis of redistributive capacity is further emphasized by research showing how social expenditure, capital taxation rates and top income growth are often dependent on partisan incumbency, and their disposition to greater or lesser degrees of regulation and social transfer (Castles and Obinger, 2007; Volscho and Kelly, 2012).

\section{Conclusion}

This analysis contributes two fundamental points to the financialization debate in particular, and to Piketty's thesis in general. First, given the general responsiveness of top incomes to measures of power resources linked to financialization, our results suggest that wealth concentration must be interpreted in terms of relative class-based and institutional power resources. Second, these results offer a wider theoretical contribution, insofar as they reassert the necessity of conceptualizing social change in terms of distinct regulatory regimes-financialization being the most recent. While the preceding results must be cautiously interpreted owing to sample limitations, they beg important questions concerning prognosis, as wider trends suggest the era of financialization to be one of the worst in terms of its capacity to enhance inequality. Our evidence shows that bargaining asymmetry is driven by a variety of factors beyond fiscal policy alone, such as regulatory control, class-based power resources, financial globalization and institutional weakening. Whilst the weight of financial sector profit and productivity has continued its upward climb relative to other economic sectors, in many 
countries-including social democracies such as Denmark for example-it continues to outstrip the real economy in terms of its contribution to productivity and growth. In light of this complexity, serious questions must be asked about the ability of capital taxation measures alone to effect redistribution in the absence of a broader reconfiguration of social relations linked to the distribution of economic reward (Piketty, 2014).

In light of our findings that FIRE sector surplus constitutes a key predictor of top income growth, and its noted role as a contributor to re-shaping the field of bargaining between capital and labour, our findings must surely raise questions concerning the ability of a fragmented labour movement, particularly in liberal market economies, to effect meaningful equality of outcome in an economy yet beholden to elite-dominated finance. This effect is especially concerning since it captures a fundamental shift not only in the organization of capitalist economies, but of the social relations under which the struggle for capitalism's rewards takes place. Recent history has shown that the shift towards finance has merely offered a tentative basis for growth, volatility for labour, yet according to our results, a reckonable channel for the resource-endowed to augment their fortunes. This analysis further underscores the importance of exploring income in terms of its factor and personal distributions, where inequality is driven both by greater capture of national product by capital relative to labour, and by a 'hollowing out' of protections associated with greater redistribution. Questions of class-biased power resources rest at the heart of these inequalities, such as control over the setting of fiscal and social policy, allocation of the burden of post-crisis austerity and a deference on the part of stricken governments to financial markets in their recovery strategies.

If we are to accept the prognosis following from Piketty's 'empirical proof' of the centrality of inequality to a functioning capitalism, the consequences of continued top income growth are likely to be dire. Harvey (2014) arrives at much the same conclusion in his diagnosis of the principal contradictions of capitalism, where he singles out the unsustainability of compound growth in a system dependent on exponential returns. Worse still, the post-war asset devaluations identified by Piketty as a principal shock to the fortunes of the wealthy have apparently done little to alter the concentration of income in the crisis of our time. Instead, the devaluation of 2008 estimated by the IMF at one year's worth of global output, offered but brief pause as property and interest-bearing assets remained largely in the hands of the wealthy (Harvey, 2014, p. 234). It is therefore ironic that the recent financial crisis has favourably exposed the 'apparatus of exploitation' embedded in capitalism's latest 'phase transition', lending credence to public debate for redistributive measures such as wealth taxation (Moreno, 2014, p. 265). Caution is required in generalizing these results however. Whilst our choice of data was driven by the need to strike a balance between eligible countries from the WTID with relevant financialization indicators, our conclusions are thus limited primarily to 'advanced capitalist democracies' (Kristal, 2010). However, many of our results are corroborated by other decomposed models which have examined advanced countries (Stockhammer, 2013), where financialization has proven a greater boon to capital shares than globalization, technological change and welfare state retrenchment.

Our results point towards the rising structural weakness of labour in the face of stressors such as the globalization of capital, the erosion of redistributive measures such as collective bargaining capacity, strong labour unions and financial regulation as key culprits in rising wealth inequality. Financialization is implicated heavily in these dynamics, not only as a principal agent in the shifting balance of power towards capital, but as a force in the erosion of 
regulatory control, as growth capacity in the developed world shifted from the real economy towards disembedded financial activity. Prescriptively, these results suggest that greater shares of state consumption, healthy labour movements, tighter regulation and stronger redistributive capacity are central to mitigating the effects of top income accumulation associated with financialization. Further, we find strong evidence that this accumulation has been driven by familiar components of the financialization narrative linked to a market-driven 'disconnect' between real growth performance and top compensation, and a side-lining of labour's interests (Stockhammer, 2012; Thompson, 2013).

Although the preceding results identify a common stressor of equality in the form of financial globalization, comparative research suggests that future work may benefit from considering variation in the impact of financialization across different 'worlds of capitalism'. Denmark's post-crisis use of collective private funds for distressed banks for example, contrasts starkly with Ireland's sector-wide deposit and liability guarantee scheme, illustrating the potential importance of cross-regime difference between liberal and social democratic political economies (Grossman and Woll, 2014). In the Irish case, the post-crisis response further entrenched inequalities between income groups by reducing the liabilities of investors, whilst redressing the fiscal balance through a wave of austerity policies, targeting public investment and welfare. This is but one example of the potential nuances which may be overlooked by an analysis at this level of abstraction. In terms of broader theory, our models suggest that a 'social structures of accumulation' approach, albeit one augmented to focus on the impact of class-biased power resources on inequality, is a productive line of inquiry. As evidence accumulates on the importance of the distribution of bargaining power between capital and labour, it is important that inequality research pays greater attention to how this bargaining power filters through regulatory orders, producing stronger concentrations of economic power and income capture.

\section{Supplementary material}

Supplementary material is available at SOCECO online.

\section{Acknowledgements}

The quality of this paper was greatly enhanced by the helpful suggestions of three anonymous reviewers, and the editor of this issue. Special thanks to Felix Behling, Rossella Ciccia, Seán Ó Riain, and Eamonn Slater for many helpful discussions, and to Chris Raymond for his advice during the later stages of this research.

\section{Funding}

This research was funded by the Irish Research Council, and the European Research council.

\section{References}

Aaberge, R. and Atkinson, A. B. (2010) 'Top Incomes in Norway'. In Atkinson, A. B. and Piketty, T. (eds) Top Incomes: A Global Perspective, Oxford, Oxford University Press, pp. 448-481.

Abiad, A., Detragiache, E. and Tressel, T. (2008) 'A New Database of Financial Reforms', IMF Working Paper WP/08/266.

Alderson, A. and Nielsen, F. (2002) 'Globalization and the Great U-Turn: Income Inequality Trends in 16 OECD Countries’, American Journal of Sociology, 107, 1244-1299. 
Alvaredo, F. and Pisano, E. (2010) 'Top Incomes in Italy, 1874-2004'. In Atkinson, A. B. and Piketty, T. (eds) Top Incomes: A Global Perspective, Oxford, Oxford University Press, pp. 625-663.

Alvaredo, F. and Saez, E. (2010) 'Income and Wealth Concentration in Spain in a Historical and Fiscal Perspective'. In Atkinson, A. B. and Piketty, T. (eds) Top Incomes: A Global Perspective, Oxford, Oxford University Press, pp. 482-559.

Alvaredo, F., Atkinson, A. B., Piketty, T. and Saez, E. (2013) 'The Top 1 Percent in International and Historical Perspective', Journal of Economic Perspectives, 27, 3-20.

Alvaredo, F., Atkinson, A. B., Piketty, T. and Saez, E. (2014) 'The World Top Incomes Database', accessed at http://topincomes.g-mond.parisschoolofeconomics.eu/ on February 17, 2014.

Atkinson, A. B. (2007) 'The Distribution of Top Incomes in the United Kingdom 1908-2000'. In Atkinson, A. B. and Piketty, T. (eds) Top Incomes Over the Twentieth Century: A Contrast Between Continental European and English-Speaking Countries, Oxford, Oxford University Press, pp. 82-140.

Atkinson, A. B. (2009) 'Factor Shares: The Principal Problem of Political Economy?', Oxford Review of Political Economy, 25, 3-16.

Atkinson, A. B. and Leigh, A. (2007a) 'The Distribution of Top Incomes in Australia'. In Atkinson, A. B. and Piketty, T. (eds) Top Incomes Over the Twentieth Century: A Contrast Between Continental European and English-Speaking Countries, Oxford, Oxford University Press, pp. 309-332.

Atkinson, A. B. and Leigh, A. (2007b) 'The Distribution of Top Incomes in New Zealand'. In Atkinson, A. B. and Piketty, T. (eds) Top Incomes Over the Twentieth Century: A Contrast Between Continental European and English-Speaking Countries, Oxford, Oxford University Press, pp. 333-364.

Atkinson, T. and Piketty, T. (eds) (2007) Top Incomes Over the Twentieth Century: A Contrast Between Continental European and English-Speaking Countries, Oxford, Oxford University Press.

Atkinson, T. and Piketty, T. (eds) (2010) Top Incomes: A Global Perspective, Oxford, Oxford University Press.

Atkinson, A. B. and Sogaard, J. E. (2013) 'The Long-Run History of Income Inequality in Denmark: Top Incomes from 1870 to 2010’, EPRU Working Paper Series, 2013-01.

Atkinson, A. B., Piketty, T. and Saez, E. (2010) 'Top Incomes in the Long Run of History'. In Atkinson, A. B. and Piketty, T. (eds) Top Incomes: A Global Perspective, Oxford, Oxford University Press, pp. 664-760.

Beckfield, J. (2006) 'European Integration and Income Inequality', American Journal of Sociology, 71, 964-985.

Beckfield, J. (2009) 'Remapping Inequality in Europe: The Net Effect of Regional Integration on Total Income Inequality in the European Union', International Journal of Comparative Sociology, 50, 486-509.

Bentolia, S. and Saint-Paul, G. (2003) 'Explaining Movements in the Labour Share', Contributions to Macroeconomics, 3, 1-33.

Bermandi, P. and Rueda, D. (2007) 'Social Democracy Constrained: Indirect Taxation in Industrialized Democracies', British Journal of Political Science, 37, 619-641.

Blanchard, O. and Giavazzi, F. (2003) 'Macroeconomic Effects of Regulation and Deregulation in Goods and Labor Markets', The Quarterly Journal of Economics, 118, 879-907.

Boyer, R. (2000) 'Is a Finance-Led Growth Regime a Viable Alternative to Fordism? A Preliminary Analysis', Economy and Society, 29, 111-145.

Castles, F. and Obinger, H. (2007) 'Social Expenditure and the Politics of Redistribution', Journal of European Social Policy, 17, 206-222.

Choi, M. (2001) 'Threat Effect of Foreign Direct Investment in Labor Union Wage Premium', Political Economy Research Institute Working Paper No. 27. 
Christophers, B. (2012) ‘Anaemic Geographies of Financialisation', New Political Economy, 17, 271-291.

Cushen, J. and Thompson, P. (2013) 'Financialization in the Workplace: Hegemonic Narratives, Performatvie Interventions and the Angry Knowledge Worker', Accounting, Organizations and Society, 38, 314-331.

Daudey, E. and García-Penalosa, C. (2007) 'The Personal and Factor Distribution of Income in a Cross-Section of Countries', The Journal of Development Studies, 43, 812-829.

Decreuse, B. and Maarek, P. (2008) 'FDI and the Labor Share in Developing Countries: A Theory and Some Evidence', Groupment de Recherche en Economie Quantitative d'Aix-MarseilleUMR-CNRS 6579, accessed at http://mpra.ub.uni-muenchen.de/11224/ on February 4, 2013.

Dell, F., Piketty, T. and Saez, E. (2007) 'Income and Wealth Concentration in Switzerland over the Twentieth Century'. In Atkinson, A. B. and Piketty, T. (eds) Top Incomes Over the Twentieth Century: A Contrast Between Continental European and English-Speaking Countries, Oxford, Oxford University Press, pp. 472-500.

de Serres, A., Scarpetta, S. and de la Maissonneuve, C. (2002) 'Sectoral shifts in Europe and the United States: how they affect aggregate labour shares and the properties of wage equations', OECD Economics Department Working Paper No. 326.

Diwan, I. (2001) 'Debt As Sweat: Labor, Financial Crises, and the Globalization of Capital', accessed at http://info.worldbank.org/etools/docs/voddocs/150/332/diwan.pdf on February 4, 2013.

Dreher, A. (2006) 'Does Globalization Affect Growth? Evidence from a new Index of Globalization', Applied Economics, 38, 1091-1110.

Dreher, A., Gaston, N. and Martens, P. (2008) Measuring Globalisation-Gauging Its Consequences, New York, Springer.

Dunhaput, P. (2015) 'An Empirical Assessment of the Contribution of Corporate Governance and Financialisation to the Rise in Income Inequality', accessed at http://recursos.march.es/web/ceacs/ actividades/miembros/duenhaupt.pdf on March 2, 2015.

Ellis, L. and Smith, K. (2007) 'The Global Upward Trend in the Profit Share', Bank for International Settlements Working Paper No. 231.

Epstein, G. and Power, D. (2003) 'Rentier incomes and Financial Crises: An Empirical Examination of the Trends and Cycles in Some OECD Countries', Canadian Journal of Development, 24, 229-248.

Flaherty, E. and Ó Riain, S. (2015) 'The Variety of Polanyian Double Movements in Europe's Capitalisms'. In Ó Riain, S., Behling, F., Ciccia, R. and Flaherty, F. (eds) The Changing Worlds and Workplaces of Capitalism, London, Palgrave Macmillan, pp. 38-57.

Forbes. (2012) 'Two Decades of CEO Pay', accessed at http://www.forbes.com/lists/2012/12/ceocompensation-12-historical-pay-chart.html on November 11, 2013.

Foster, J. B. and Holleman, H. (2010) 'The Financial Power Elite', Monthly Review, 62, 1-19.

GINI (2011) 'Inequalities Impacts; State of the Art Review', accessed at http://www.gini-research. org/system/uploads/253/original/GINI_State-of-the-Art_review_1.pdf?1308916502 on September 16, 2013.

Grossman, E. and Woll, C. (2014) 'Saving the Banks: The Political Economy of Bailouts', Comparative Political Studies, 47, 574-600.

Guscina, A. (2006) 'Effects of Globalization on Labor's Share in National Income', IMF Working Paper 06/294.

Guttman, R. (2008) 'A Primer on Finance-Led Capitalism and Its Crisis', Revue de la Regulation, 3/4, accessed at http://regulation.revues.org/5843 on September 16, 2013.

Guttman, R. and Plihon, D. (2008) 'Consumer Debt at the Center of Finance-Led Capitalism', Texte d'une Communication au Colloque International Organise á Paris par le CEPN at le SCEPA, accessed at http://www.univ-paris13.fr/CEPN/IMG/pdf/wp2008_09.pdf on August 4, 2014. 
Harrison, A. E. (2005) 'Has Globalization eroded Labor's Share?: Some Cross-Country Evidence', Unpublished Working Manuscript, accessed at http://mpra.ub.uni-muenchen.de/39649/ on February 4, 2013.

Harvey, D. (2014) Seventeen Contradictions and the End of Capitalism, London, Profile Books.

Heston, A., Summers, R. and Bettina, A. (2012) Penn World Table Version 7.1. Centre for International Comparisons of Production, Income and Prices at the University of Pennsylvania, July 2012.

Hicks, A. (2014) 'Financialisation and the 1\%', Paper Presented at Conference on Financialisation and its Consequences, Instituto Carlos III-Juan March de Ciencias Sociales, Universidad Carlos III de Madrid, June 12-13.

Hoechle, D. (2007) 'Robust Standard Errors for Panel Regressions with Cross-Sectional Dependence', The Stata Journal, 7, 281-312.

International Labour Organization (2013) Global Wage Report 2012/13: Wages and Equitable Growth, Geneva, International Labour Office.

Jantti, M., Riihela, M., Sullstrom, R. and Tuomala, M. (2010) 'Trends in Top Income Shares in Finland'. In Atkinson, A. B. and Piketty, T. (eds) Top Incomes: A Global Perspective, Oxford, Oxford University Press, pp. 371-447.

Jayadev, A. (2007) 'Capital Account Openness and the Labour Share of Income', Cambridge Journal of Economics, 31, 423-443.

Jessop, B. (2001) 'State Theory, Regulation, and Autopoiesis: Debates and Controversies', Capital and Class, 25, 83-92.

Jessop, B. (2013) 'Revisiting the Regulation Approach: Critical Reflections on the Contradictions, Dilemmas, Fixes and Crisis Dynamics of Growth Regimes', Capital and Class, 37, 5-24.

Kim, J. W., Kogut, B. and Yang, Jae-Suk. (2015) 'Executive Compensation, Fat Cats, and Best Athletes', American Sociological Review, 80, 299-328.

Kotz, D. M. (2003) 'Neoliberalism and the Social Structure of Accumulation Theory of Long-Run Capital Accumulation', Review of Radical Political Economics, 35, 263-270.

Krippner, G. (2005) 'The Financialisation of the American Economy', Socio-Economic Review, 3, 173-208.

Krippner, G. (2011) Capitalizing on Crisis: The Political Origins of the Rise of Finance, Cambridge, Harvard University Press.

Kristal, T. (2010) 'Good Times, Bad Times: Postwar Labor's Share of National Income in Capitalist Democracies', American Sociological Review, 75, 729-763.

Kus, B. (2012) 'Financialisation and Income Inequality in OECD Nations: 1995-2007', The Economic and Social Review, 43, 477-495.

Kus, B. (2013a) 'Credit, Consumption and debt: Comparative Perspectives', International Journal of Comparative Sociology, 54, 183-186.

Kus, B. (2013b) 'Consumption and Redistributive Politics: The Effect of Credit and China', International Journal of Comparative Sociology, 54, 187-204.

Lane, P. and Milesi-Ferretti, G. M. (2007) 'The External Wealth of Nations Mark II: Revised and Extended Estimates of Foreign Assets and Liabilities, 1970-2004', Journal of International Economics, 73, 223-250.

Leigh, A. (2007) 'How Closely Do Top Income Shares Track Other Measures of Inequality?', The Economic Journal, 117, 619-633.

Lin, K. and Tomaskovic-Devey, D. (2013) 'Financialization and US. Income Inequality, 19702008', American Journal of Sociology, 118, 1284-1329.

McDonough, T., Reich, M. and Kotz, D. M. (2010) Contemporary Capitalism and Its Crisis, Cambridge, Cambridge University Press.

Moreno, L. (2014) 'The Urban Process Under Financialised Capitalism', City, Online First, 18, 244-268. 
Moriguchi, C. and Saez, E. (2010) 'The Evolution of Income Concentration in Japan, 1886-2005: Evidence from Income Tax Statistics'. In Atkinson, A. B. and Piketty, T. (eds) Top Incomes: A Global Perspective, Oxford University Press, pp. 76-170.

Movitz, F. and Allvin, M. (2014) 'What Does Financial Derivatives Really Got to Do with Jobs? Examining Causal Mechanisms between Aspects of Financialization, Work Intensification and Employment Insecurity', Paper for ILPC 7-9th March 2014, London.

Nolan, B. (2007) 'Long-Term Trends in Top Income Shares in Ireland'. In Atkinson, A. B. and Piketty, T. (eds) Top Incomes Over the Twentieth Century: A Contrast Between Continental European and English-Speaking Countries, Oxford, Oxford University Press, pp. 501-530.

OECD (2014) 'Rising Inequality: Youth and Poor Fall Further Behind', OECD Statistics Directorate, accessed at http://www.oecd.org/els/soc/OECD2014-Income-Inequality-Update.pdf on July 18, 2014.

O' Farrell, R. (2010) 'The Effect of International Trade on Trade Union Density', European University Institute, European Trade Union Institute Working Paper.

Ó Riain, S. (2014) The Rise and Fall of Ireland's Celtic Tiger: Liberalism, Boom and Bust, Cambridge, Cambridge University Press.

Piketty, T. (2007) 'Income, Wage, and Wealth Inequality in France'. In Atkinson, A. B. and Piketty, T. (eds) Top Incomes Over the Twentieth Century: A Contrast Between Continental European and English-Speaking Countries, Oxford, Oxford University Press, pp. 43-81.

Piketty, T. (2014) Capital in the Twenty-First Century, Cambridge, Harvard University Press.

Piketty, T. and Saez, E. (2007) 'Income and Wage Inequality in the United States, 1913-2002'. In Atkinson, A. B. and Piketty, T. (eds) Top Incomes Over the Twentieth Century: A Contrast Between Continental European and English-Speaking Countries, Oxford, Oxford University Press, pp. 141-225.

Rabe-Hesketh, S. and Skrondal, A. (2012) Multilevel and Longitudinal Modeling Using Stata, Volume 1: Continuous Responses, 3rd edn, Texas, Stata Press.

Roine, J. and Waldenstrom, D. (2010) 'Top Incomes in Sweden over the Twentieth Century'. In Atkinson, A. B. and Piketty, T. (eds) Top Incomes: A Global Perspective, Oxford, Oxford University Press, pp. 299-370.

Rueda, D. and Pontusson, J. (2000) 'Wage Inequality and Varieties of Capitalism', World Politics, $52,350-383$.

Solt, F. (2009) 'Standardizing the World Income Inequality Database', Social Science Quarterly, 90, 231-242.

Stockhammer, E. (2004) 'Financialization and the Slowdown of Accumulation', Cambridge Journal of Economics, 28, 719-741.

Stockhammer, E. (2009) 'The Finance-Dominated Accumulation Regime, Income Distribution and the Present Crisis', Department of Economics Working Paper Series, 127. Inst. Fur Volkswirtschaftstheorie und politik, WU Vienna University of Economics and Business, Vienna.

Stockhammer, E. (2012) 'Financialization, Income Distribution and the Crisis', Investigación Económica, 71, 39-70.

Stockhammer, E. (2013) 'Why Have Wage Shares Fallen? A Panel Analysis of the Determinants of Functional Income Distribution', International Labour Office, Conditions of Work and Employment Series.

Tabb, W. K. (2010) 'Financialization in the Contemporary Social Structure of Accumulation'. In McDonough, T., Reich, M. and Kotz, D.M. (eds) Contemporary Capitalism and Its Crises, Cambridge, Cambridge University Press, pp. 145-167.

Thompson, P. (2003) 'Disconnected Capitalism: Or Why Employers Can't Keep Their Side of the Bargain', Work, Employment and Society, 17, 359-378. 
Thompson, P. (2013) 'Financialisation and the Workplace: Extending and Applying the Disconnected Capitalism Thesis', Work, Employment and Society, 27, 472-488.

Tomaskovic-Devey, D. and Lin, K. (2011) 'Income Dynamics, Economic Rents, and the Financialization of the U.S. Economy', American Journal of Sociology, 76, 538-559.

Tomaskovic-Devey, D. and Lin, K. (2013) 'Financialization: Causes, Inequality Consequences, and Policy Implications', North Carolina Banking Institute Journal, 18, 167-194.

Tomaskovic-Devey, D., Lin, K. and Meyers, N. (2014) 'Did Financialization Decrease Economic Well-Being?', Paper for 'Financialization and Its Consequences', Juan March Institute, Madrid June 2014.

Van der Zwan, N. (2014) ‘Making Sense of Financialization', Socio-Economic Review, 12, 99-129.

Visser, J. (2013) 'Database on Institutional Characteristics of Trade Unions, Wage Setting, State Intervention and Social Pacts in 34 Countries Between 1960 and 2012', accessed at http://www.uva-aias.net/207 on February 17, 2014.

Volscho, T. W. and Kelly, N. J. (2012) 'The Rise of the Super-Rich: Power Resources, Taxes, Financial Markets, and the Dynamics of the Top 1 Percent, 1949 to 2008', American Sociological Review, 77, 679-699.

Woolridge, J. (2013) Introductory Econometrics: A Modern Approach. Boston, Cengage Learning. Zuleta, H. (2012) 'Variable Factor Shares, Measurement and Growth Accounting', Economic Letters, 114, 91-93.

\section{Appendix A}

Table A1 reports panel unit root tests for all relevant interval variables included in the model. Unit root tests were performed using the Augmented Dickey-Fuller (ADF) sub-selection of Fisher-type tests. The following tests assume an AR1 autoregressive process and are repeated using demeaned variables to account for cross-unit heterogeneity. For all tests, $\mathrm{H}_{0}$ : all panels contain unit roots; $\mathrm{H}_{a}$ : at least one panel is stationary. The results indicate that although unit root processes appear in a select number of variables, the diagnostics respond favourably to demeaning. These results lend further credence to the utility of a within-estimator, as the demeaned adjustment also subtracts crosssection averages from individual series. A majority of variables-as well as the demeaned dependent variable, government consumption and market capitalization—indicate absent or ambiguous evidence of a unit root amongst all panels. 
Table A1. Unit root diagnostics

Panel unit root tests (AR1)

\begin{tabular}{|c|c|c|c|c|}
\hline Variable & $\begin{array}{l}\text { Inverse } \\
\text { chi-square } \\
\left(X^{2}\right)\end{array}$ & $\begin{array}{l}\text { Inverse } \\
\text { normal }(Z)\end{array}$ & $\begin{array}{l}\text { Inverse } \\
\text { chi-square, } \\
\text { demeaned }\left(X^{2}\right)\end{array}$ & $\begin{array}{l}\text { Inverse normal, } \\
\text { demeaned }(Z)\end{array}$ \\
\hline Top $1 \%$ income share & 27.37 & 0.26 & $50.42 *$ & -1.11 \\
\hline Government consumption & $74.54 *$ & -0.10 & $92.12 * * *$ & $-2.04 *$ \\
\hline Union density & $154.42 * * *$ & $-2.69 * *$ & $75.13 *$ & 0.56 \\
\hline Economic globalization & $158.53 * * *$ & $-7.24 * * *$ & 69.83 & -1.57 \\
\hline Trade openness & 47.61 & 1.21 & 57.95 & 1.1 \\
\hline Unemployment & $106.30 * * *$ & $-4.79 * * *$ & $125.03 * * *$ & $-4.53 * * *$ \\
\hline $\begin{array}{c}\text { Female labour force } \\
\text { participation }\end{array}$ & 61.56 & 2.13 & 70.33 & -0.40 \\
\hline $\begin{array}{l}\text { Market capitalization of listed } \\
\text { firms (\% GDP) }\end{array}$ & 67.28 & $-2.61 * *$ & $69.77^{*}$ & $-2.06^{*}$ \\
\hline Private sector credit ( $\%$ GDP) & 42.03 & 3.67 & 48.82 & 1.84 \\
\hline $\begin{array}{c}\text { Finance, Insurance, and Real } \\
\text { Estate Gross Operating } \\
\text { Surplus (\% all sectors) }\end{array}$ & 62.80 & 1.13 & $81.97 * *$ & 0.14 \\
\hline $\begin{array}{l}\text { Labour's share of Gross } \\
\text { National Income }\end{array}$ & $136.72 * * *$ & $-4.02 * * *$ & $139.87 * *$ & $-4.57 * * *$ \\
\hline Financial globalization (log) & 6.43 & 9.19 & 26.53 & 5.55 \\
\hline $\begin{array}{l}\text { Economic growth (real GDP \% } \\
\text { yearly change) }\end{array}$ & $248.09 * * *$ & $-10.95 * *$ & $314.36 * * *$ & $-12.58 * * *$ \\
\hline $\begin{array}{l}\text { Capital taxation (\% total tax } \\
\text { burden) }\end{array}$ & $131.82 * * *$ & $-1.93 * * *$ & $97.53 * *$ & $-3.17 * * *$ \\
\hline $\begin{array}{l}\text { Indirect taxation (\% total tax } \\
\text { burden) }\end{array}$ & $126.02 * * *$ & $-4.37 * * *$ & $134.90 * * *$ & $-4.45 * *$ \\
\hline Net income inequality (Gini) & $137.62 * * *$ & $-3.88 * * *$ & $134.59 * * *$ & $-4.77 * * *$ \\
\hline Financial reform index & $377.13 * * *$ & $-11.69 * * *$ & $274.43 * * *$ & $-9.24 * * *$ \\
\hline Political globalization & $379.98 * * *$ & $-13.21 * *$ & $197.00 * * *$ & $-6.11 * * *$ \\
\hline
\end{tabular}

${ }^{*} P \leq 0.05 ; * P \leq 0.01 ; * * P \leq 0.001$. 


\section{Appendix B}

Table B1. Notes on the measurement of top incomes

\begin{tabular}{|c|c|c|}
\hline Country & Measure (income definition) & $\begin{array}{l}\text { Column title fron } \\
\text { WTID }\end{array}$ \\
\hline Australia & $\begin{array}{l}\text { Tax unit is the individual, control total for population is that aged } \\
15 \text { and over, control total for income is national accounts total } \\
\text { of personal income with non-household items excluded } \\
\text { (charities, universities, social security contributions, } \\
\text { non-taxable payments). Australia uses 'actual income' concept } \\
\text { from } 1958 \text { (pre-eligible deductions). Some gains are included } \\
\text { under regular income tax, but others are excluded (as with UK) } \\
\text { since } 1986 \text { under separate capital gains system (Atkinson and } \\
\text { Leigh } 2007 a \text { ). }\end{array}$ & $\begin{array}{l}\text { Top } 1 \% \text { income } \\
\text { share }\end{array}$ \\
\hline Denmark & $\begin{array}{l}\text { Danish statistics offer a number of advantages such as a stable } \\
\text { long-term tax code, centralized data collection and detailed } \\
\text { tabulation. The taxable gross income concept excludes realized } \\
\text { capital gains, but includes transfers such as unemployment and } \\
\text { sickness benefit, and public pensions. Prior to } 1980 \text { where } \\
\text { subtle variation is introduced owing to the availability of } \\
\text { micro-data, the income concept included wage income and } \\
\text { transfers, stock and dividend gains, and net business income. } \\
\text { Tax units from } 1970 \text { are individuals aged } 15 \text { and over, and the } \\
\text { control totals are derived from the actual number of tax units } \\
\text { (Atkinson and Sogaard, 2013). }\end{array}$ & $\begin{array}{c}\text { Top } 1 \% \text { income } \\
\text { share adults }\end{array}$ \\
\hline Finland & $\begin{array}{l}\text { Data are sourced from the Income Distribution Surveys (IDS) and } \\
\text { Household Expenditure Surveys. Although the IDS is a } \\
\text { representative sample survey, it draws information on income, } \\
\text { taxes and benefits from administrative registers. These income } \\
\text { estimates include sources such as labour and entrepreneurial } \\
\text { income, capital income and received transfers. Realised capital } \\
\text { gains are taxable after } 1993 \text { reforms, however, state capital } \\
\text { income tax and property tax are subtracted under their income } \\
\text { definition. After 1975, jointly taxed persons were no longer } \\
\text { assessed as a single taxable unit. The authors note that rising } \\
\text { Gini income inequality has been driven strongly by increases in } \\
\text { top income shares since the 1990s (Jantti et al., 2010). }\end{array}$ & $\begin{array}{c}\text { Top } 1 \% \text { income } \\
\text { share IDS }\end{array}$ \\
\hline France & $\begin{array}{l}\text { Tabulations since } 1915 \text { list all individual income tax returns, and } \\
\text { the income concept is pre-tax, pre-deduction taxable income. A } \\
\text { key feature of the evolving composition of French top incomes } \\
\text { is a decline in the share of wage income in top fractiles, a rising } \\
\text { share of capital income (dividends, interest, rents). French top } \\
\text { incomes thus derive mainly from dividends, and large capital } \\
\text { owners are predominantly shareholders, not bondholders or } \\
\text { landlords (Piketty, 2007). }\end{array}$ & $\begin{array}{l}\text { Top } 1 \% \text { income } \\
\text { share }\end{array}$ \\
\hline
\end{tabular}


Table B1. Continued

\begin{tabular}{|c|c|c|}
\hline Country & Measure (income definition) & $\begin{array}{l}\text { Column title from } \\
\text { WTID }\end{array}$ \\
\hline Ireland & $\begin{array}{l}\text { Income definition from } 1970 \text { is 'total income', which is net of } \\
\text { capital allowances, retirement annuities and interest paid. Tax } \\
\text { unit is the single adult or married couple with dependent } \\
\text { children, with control population total derived from census } \\
\text { years through interpolation. Control total for aggregate income } \\
\text { follows the USA, where aggregate personal sector income from } \\
\text { national accounts is adjusted for transfers and social insurance } \\
\text { contributions. By } 2000 \text {, self-employed income comprised } 69 \% \\
\text { of the income of the top } 1 \% \text { group, whilst predominantly } \\
\text { unearned income accounts only for } 4 \% \text { of top income cases } \\
\text { (Nolan, 2007). }\end{array}$ & $\begin{array}{l}\text { Top } 1 \% \text { income } \\
\text { share }\end{array}$ \\
\hline Italy & $\begin{array}{l}\text { Calculations are performed on personal income tax data compiled } \\
\text { by the Italian tax administration, and the income concept is } \\
\text { gross income before deductions, and including income items } \\
\text { such as salaries, pension, self-employment income, dividends } \\
\text { and real estate. Controls population totals are derived from } \\
\text { census data, and the tax unit since } 1976 \text { is the individual. } \\
\text { Realized capital gains are mostly excluded, but the series some } \\
\text { gains from qualified equities. The control income denominator } \\
\text { is calculated from national accounts data on wages and salaries, } \\
\text { pensions, business income and non-labour income. The authors } \\
\text { note that evasion on wages, salaries and pensions at the top of } \\
\text { the distribution is low, as evasion rates tend to decrease with } \\
\text { true income (Alvaredo and Pisano, 2010). }\end{array}$ & $\begin{array}{l}\text { Top } 1 \% \text { income } \\
\text { share }\end{array}$ \\
\hline Japan & $\begin{array}{l}\text { Data are soured from income tax statistics published by the } \\
\text { Japanese tax administration, and the income concept is gross } \\
\text { income before individual tax liabilities, but after employers } \\
\text { payroll and corporate income tax. This includes all income } \\
\text { components reported in tax returns, such as salaries and wages, } \\
\text { business and farm income, self-employment income, dividends, } \\
\text { interest and rent, with realized capital gains excluded owing to } \\
\text { their volatility. The tax unit is the individual, and control totals } \\
\text { are calculated from counts of total adults, and from national } \\
\text { accounts figures of total personal income (Moriguchi and Saez, } \\
\text { 2010). }\end{array}$ & $\begin{array}{l}\text { Top } 1 \% \text { income } \\
\text { share }\end{array}$ \\
\hline New Zealand & $\begin{array}{l}\text { The tax unit since } 1953 \text { is the individual, and the control is the } \\
\text { number of people aged } 15 \text { and over. The income total is pre-tax } \\
\text { gross income, and the control total is derived from adjusted } \\
\text { national accounts household income totals, including transfers. } \\
\text { Realized capital gains are excluded, whist dividends are covered } \\
\text { by the estimates. An increase of the marginal tax rate on } \\
\text { incomes over US\$ } 60000 \text { from } 33-39 \% \text { in } 2000 \text {, led to } \\
\text { extensive realization of business earnings in } 1999 \text {, whilst a fully } \\
\text { separate system of capital gains returns was established during } \\
\text { the same tax year (Atkinson and Leigh } 2007 b, \text { p. 339). }\end{array}$ & $\begin{array}{c}\text { Top } 1 \% \text { income } \\
\text { share adults }\end{array}$ \\
\hline
\end{tabular}


Table B1. Continued

\begin{tabular}{|c|c|c|}
\hline Country & Measure (income definition) & $\begin{array}{l}\text { Column title from } \\
\text { WTID }\end{array}$ \\
\hline Norway & $\begin{array}{l}\text { The calculation procedure follows closely that of Piketty for } \\
\text { France. Data on incomes are derived from tax register } \\
\text { micro-data files, supplemented with Income Distribution } \\
\text { Survey data. Taxation is generally joint, although separate } \\
\text { filing for two-earner couples has increased. Control totals for } \\
\text { population include adults aged } 16 \text { and over, and the control } \\
\text { income total relies on national accounts total household } \\
\text { income data. These include employment income, interest, } \\
\text { rents, dividends and transfers (Aaberge and Atkinson, 2010). }\end{array}$ & $\begin{array}{l}\text { Top } 1 \% \text { income } \\
\text { share }\end{array}$ \\
\hline Spain & $\begin{array}{l}\text { Estimates are compiled from personal income and wealth returns } \\
\text { to the Spanish fiscal administration, where the tax unit since } \\
1988 \text { is the individual. The income concept is gross income, } \\
\text { pre-deduction and incorporating all tax schedule items such as } \\
\text { salaries and pensions, self-employment income, business } \\
\text { income, dividends and interest. Although realized capital } \\
\text { gains are included in the tax base, a series excluding them is } \\
\text { provided and used for this study. Control population totals are } \\
\text { derived from census data of total adults, and control income } \\
\text { totals are derived from national accounts and GDP data. } \\
\text { Reinforcing the necessity of tax-based methodologies, Spanish } \\
\text { survey measures have shown a reduction in income inequality } \\
\text { and relative stability post-1980, whilst tax-based measures } \\
\text { show worsening throughout the 1990s (Alvaredo and Saez, } \\
\text { 2010). }\end{array}$ & $\begin{array}{l}\text { Top } 1 \% \text { income } \\
\text { share }\end{array}$ \\
\hline Sweden & $\begin{array}{l}\text { Income data are derived from annual published income } \\
\text { distribution statistics, the income concept is all-source gross } \\
\text { income before taxes and transfers, less source interest } \\
\text { payments. Although the concept includes realized capital } \\
\text { gains, the data are structured in a way which allows them to be } \\
\text { subtracted from the series. The final income total includes } \\
\text { labour, capital and business income less realized capital gains. } \\
\text { Control totals for population and income are derived from the } \\
\text { adults population recorded by Statistics Sweden, and a } \\
\text { combination of national accounts data and Swedish tax } \\
\text { statistics, respectively. }\end{array}$ & $\begin{array}{l}\text { Top } 1 \% \text { income } \\
\text { share }\end{array}$ \\
\hline
\end{tabular}


Table B1. Continued

\begin{tabular}{|c|c|c|}
\hline Country & Measure (income definition) & $\begin{array}{l}\text { Column title from } \\
\text { WTID }\end{array}$ \\
\hline Switzerland & $\begin{array}{l}\text { Income definition is 'Revenu net' income before deductions, which } \\
\text { includes employment, business and capital income, excluding } \\
\text { realized capital gains. The Swiss tax unit is at family level } \\
\text { (married couple, or single person with dependents). Decennial } \\
\text { census' are used to calculate control population totals through } \\
\text { interpolation, and the control income total is the total of tax } \\
\text { returned income with adjustment for non-returners. This total } \\
\text { income is defined as personal income including transfers, and } \\
\text { after-tax corporate profits after distribution of dividends. } \\
\text { Switzerland maintains a very low top marginal income tax rate } \\
\text { (10\%); there is no federal inheritance or estate tax, and most } \\
\text { counties do not levy inheritance taxes between spouses, parents } \\
\text { or children. Thus the marginal tax rate on local and capital } \\
\text { income has been very low relative to OECD comparators. } \\
\text { Complete tax avoision is difficult however, as returns on wealth } \\
\text { invested are flat-taxed } 35 \% \text { at source. Whilst the use of flat-rate } \\
\text { allows for a level of secrecy around account ownership, it } \\
\text { allows for estimates of the proportion of non-Swiss filing } \\
\text { income tax returns (Dell et al., 2007). }\end{array}$ & $\begin{array}{l}\text { Top } 1 \% \text { income } \\
\text { share }\end{array}$ \\
\hline UK & $\begin{array}{l}\text { UK tax base figures do not correspond with definite income } \\
\text { definition, and thus omit most capital gains and losses (note } \\
\text { that there is a time effect here which lends some confidence to } \\
\text { the consistency of figures within the timeframe under } \\
\text { consideration within this study - whilst the effect of capital } \\
\text { gains and losses over time cannot be assumed uniform as } \\
\text { verified by the US case, incentives for tax avoidance fall within } \\
\text { changes to policy, which tend to be less frequent). Units for top } \\
\text { income estimates are individuals, and the control total for } \\
\text { income is the total from income tax statistics with an added } \\
\text { estimate of the income of units not covered. In } 1997 \text {, the share } \\
\text { of investment income of the top } 1 \% \text { was approximately } 12 \% \\
\text { (Atkinson, } 2007, \text { p. } 110 \text { ). }\end{array}$ & $\begin{array}{c}\text { Top } 1 \% \text { income } \\
\text { share adults }\end{array}$ \\
\hline USA & $\begin{array}{l}\text { Tax unit is the married couple or single adult with dependents. } \\
\text { Calculations use a gross income definition which includes all } \\
\text { income items on tax returns before deduction (salaries and } \\
\text { wages, farm income, dividends, interest, rents). Realized capital } \\
\text { gains are not an annual flow of income and form a volatile } \\
\text { component of income with large variations dependent on stock } \\
\text { prices, thus the preferred series for comparability is the series } \\
\text { with excluded capital gains (Piketty and Saez, 2007, p. 144, } \\
\text { 195). Piketty and Saez show that for the USA, although } \\
\text { measurement and taxation of capital gains are important, it is } \\
\text { not the primary driving force behind changing trends. }\end{array}$ & $\begin{array}{l}\text { Top } 1 \% \text { income } \\
\text { share }\end{array}$ \\
\hline
\end{tabular}

